\title{
The Fed's Discount Window: An Overview of Recent Data
}

Felix P. Ackon and Huberto M. Ennis

$\mathrm{T}$ he Dodd-Frank Act of 2010 requires the Federal Reserve to publish data on discount-window transactions with approximately two years' delay, starting from the passage of the Act in July 2010. The availability of these data provides an opportunity, for policymakers and researchers alike, to get a more detailed perspective on the nature of lending in this important and traditional central bank credit facility.

The Fed provides credit through the discount window using three different programs: primary credit, secondary credit, and seasonal credit. Primary credit and secondary credit are emergency credit programs. These programs constitute a backup source of short-term funding for eligible financial institutions. Seasonal credit is aimed at smaller institutions with a predictable (and demonstrable) seasonal pattern in their funding needs. Each loan must be secured by collateral from the borrowing institution.

The primary-credit program is a standing facility in which depository institutions in good financial conditions (in the form of a high score on their examination rating) can access (mainly) overnight funding with "no questions asked" and at an interest rate higher than the target policy short-term rate. Those institutions not eligible for primary credit can receive secondary credit.

Normally, secondary credit is offered at a rate that is fifty basis points above the primary-credit rate. Furthermore, secondary-credit

- We would like to thank Chris Mast for helpful discussions and Caroline Davis, Doug Diamond, Borys Grochulski, Beth Klee, Steve McCarther, John Walter, and John Weinberg for comments on a previous draft. The views expressed in this article are those of the authors and do not necessarily represent the views of the Federal Reserve Bank of Richmond or the Federal Reserve System. E-mails: Felix.Ackon@rich.frb.org; Huberto.Ennis@rich.frb.org.

DOI: https://doi.org/10.21144/eq1030102 
loans are subject to an extra degree of scrutiny (by the Fed) and cannot be used for certain purposes, such as interest rate arbitrage.

To receive seasonal credit, a financial institution must have a demonstrated seasonal need for funding and an approved seasonal line of credit with its corresponding Reserve Bank. The interest rate is a floating rate that is calculated based on the average of some selected rates in the money market - it is not intended to be a penalty rate like the others (the interest rates at the primary- and secondary-credit programs). A bank that is able to receive seasonal credit can also tap the primarycredit program if the need arises and the bank is in sound financial condition.

There is an extensive theoretical literature exploring issues related to the provision of discount-window credit by a central bank (see Ennis [2016] for a recent review). However, the empirical literature is much more scant. ${ }^{1}$ One obvious reason for this situation is that, over the years, disaggregated data on discount window activity have not been made available to the public or researchers on a regular basis. There are (potentially) good reasons for this lack of transparency: central banks are often concerned about the possibility that some degree of stigma is associated with accessing the discount window (for a discussion of this issue see, for example, Courtois and Ennis [2010]). By keeping loan information private, central banks seek to minimize the incidence of stigma.

On the other hand, more information is a constant demand from stakeholders looking to oversee the central bank's activities. The desire for more transparency was duly recognized in the Dodd-Frank Act, and, as a result, a detailed description of the Fed's discount-window actions is now easily accessible on the internet with a two-year lag, approximately. We take advantage of the new data availability in this paper and provide an overview of the main patterns identifiable in such data so far.

The paper is organized as follows. In the next section, we discuss the data used as well as some preliminary statistics. In Section 2, we present information about primary-credit loans. In Section 3, we study

\footnotetext{
${ }^{1}$ There is some empirical work on emergency lending by government institutions in the US. The early work by Furfine (2003), for example, uses data on market transactions and interest rates and compares that information with the interest rate and volume at the Fed's discount window to infer the attitudes of market participants toward central bank liquidity provision. More recently, several studies have used data on the Term Auction Facility to study different aspects of how emergency credit provision worked during the recent financial crisis (see, for example, Benmelech [2012], Berger et al. [2017], and Armantier et al. [2015]). From a historical perspective, Anbil (2015) and Vossmeyer (2017) study borrowing from the Reconstruction Finance Corporation during the Great Depression. Finally, for a detailed study of the European experience during the recent crisis, see Drechsler et al. (2016).
} 
Table 1 Discount Window Lending-Totals

\begin{tabular}{lccc}
\hline & $\begin{array}{c}\text { Total number } \\
\text { of loans }\end{array}$ & $\begin{array}{c}\text { Total number } \\
\text { of loans } \leq \mathbf{\$ 1 0 , 0 0 0}\end{array}$ & $\begin{array}{c}\text { Total amount } \\
\text { lent } \mathbf{( \$ \mathbf { m } )}\end{array}$ \\
\cline { 2 - 4 } All & 16514 & 5277 & 36124.977 \\
Primary credit & 11429 & 4655 & 26286.218 \\
Secondary credit & 650 & 611 & 118.976 \\
Seasonal credit & 4435 & 11 & 9719.781 \\
\hline
\end{tabular}

Note: We use all the data in our sample for these calculations. In a few cases, a given loan entry is composed of multiple loans to the same institution with the same term but, possibly, different amounts, which are consolidated in one entry for the purpose of reporting.

secondary-credit loans, and in Section 4, seasonal credit. Section 5 provides an analysis of the collateral pledged by borrowing banks to their corresponding Reserve Banks. Finally, Section 6 concludes.

\section{THE DATA}

Our data are a comprehensive list of discount-window loans made by Federal Reserve Banks between July 22, 2010, and June 30, 2015. The Federal Reserve releases the information on a quarterly basis, with approximately a two-year lag. The data for the second quarter of 2015 are the most recent data available at the time of this writing.

There are 16,514 individual loan observations. In some cases, an observation is the result of the consolidation of several loans granted to the same borrower on the same day with the same term to maturity. Furthermore, some loans in the sample are the consequence of a bank rolling over a previous loan. In those cases, loans are counted separately (i.e., a loan taken for one day and rolled over for a second day counts as two independent loans if at origination each of the loans was granted as an overnight loan).

For each loan, the data include: the date the loan was granted, the term to maturity, the date the loan was repaid, the name and location of the borrower and the Reserve Bank playing the role of lender, the type of credit (primary, secondary, or seasonal), the interest rate and loan amount, whether the bank had other loans outstanding, and a description of the collateral pledged by the borrowing bank.

Because the target policy rate (or range) did not change during the sample period, all primary-credit loans in the sample were granted at the same interest rate of 0.75 percent and all secondary-credit loans but one were granted at the interest rate of 1.25 percent (see Section 3 for a detailed discussion of the exceptional loan). 
Many of the loans in the sample are likely to be "test" loans. These are loans that depository institutions take in order to test whether the systems involved in processing a discount-window loan are working as expected. Test loans are generally for a very small amount: $\$ 1,000$ is probably the most common amount, but most of the $\$ 10,000$ loans in our sample are likely to also be tests, and a few loans of larger amounts may also be tests.

Unfortunately, the data available do not include information about whether a given loan is a test or not. There are a lot of $\$ 1,000$ loans in the data: 27 percent of the primary-credit loans in the data are $\$ 1,000$ or less. For secondary-credit loans, the percentage of loans with amounts at or below $\$ 1,000$ is much higher, 82 percent. If we take an even more conservative approach and consider test loans as all loans for amounts equal to or less than $\$ 10,000$ in order to identify more accurately actual credit events, then we can see from Table 1 that about a third of the loans were in that category.

Table 1 also reports the number of loans granted under the different programs. Two-thirds of the loans were granted under the primarycredit program. Interestingly, there seem to be a lot fewer test loans happening in the seasonal-credit program. Using our threshold for test loans (amounts less than or equal to $\$ 10,000$ ), we calculate that the number of nontest loans in the primary-credit and seasonal-credit programs is comparable. In contrast, the number of secondary-credit nontest loans is much less (around forty).

The total amount lent, instead, is much higher in the primarycredit program. For calculating the total amount lent, excluding the test loans does not make much of a difference. For example, the total value of all primary-credit loans with a face value equal to or below $\$ 10,000$ is approximately $\$ 18$ million, which is much less than 1 percent of the total amount lent ( $\$ 26.3$ billion, as reported in the third column of Table 1). It seems clear from these numbers, then, that the primary-credit program is the more active and significant lending program operated by the Fed's discount window.

Since the proportion of test loans is very different across different programs, to get a sense of the size of the typical loans in each program, it is important to take into account the implied composition effect. To this end, Table 2 reports some basic statistics when we exclude from the sample all loans of $\$ 10,000$ or less. We see in the table that the average size of loans is similar for primary and secondary credit and relatively smaller for seasonal-credit loans. Interestingly, the largest primary-credit loan in the sample is several orders of magnitude larger than the largest loans in the other two programs. 


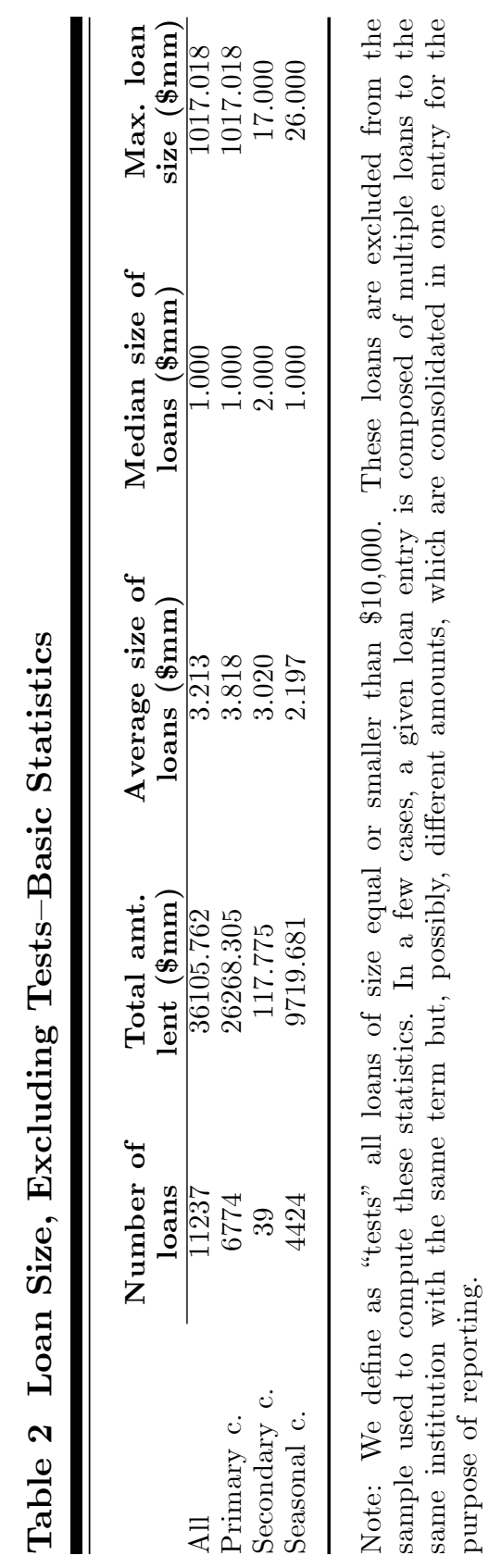




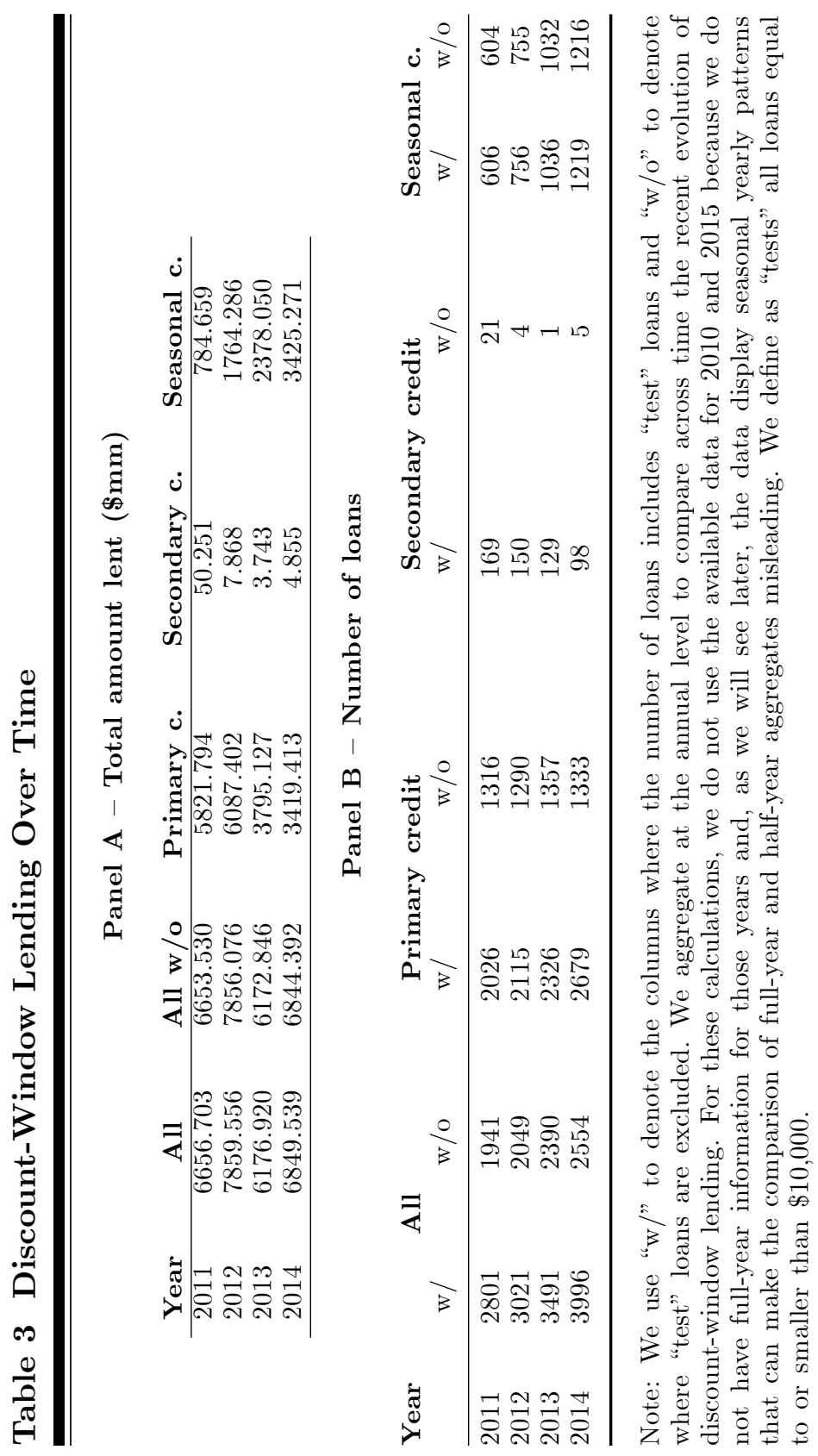


Table 3 gives a sense of the evolution over (recent) time of the amount of credit provided through the discount window. We choose to aggregate loans on an annual basis because, as we will discuss later, credit activity exhibits some yearly seasonal patterns.

The total amount lent is relatively stable between the years 2011 and 2014 (see Panel A of Table 3). ${ }^{2}$ This relative stability is the combination of two trends: on one side, the amount of lending in the primary-credit facility decreased significantly (a 40 percent drop) after 2012. On the other side, the total amount lent at the seasonal-credit facility has been increasing over time.

The total amount lent through the secondary-credit facility was relatively large in 2011 but became much smaller in the years after that. It is possible that the repercussions of the financial crisis were still driving banks to borrow secondary credit, as this is the facility available for banks in weaker financial condition. In support of that possibility, note that, for example, the number of "problem banks" in the US (as reported by the Federal Deposit Insurance Corporation [FDIC]) peaked in 2011 at (around) 900 and since then has been experiencing a steady decline, reaching 200 in 2015.

Panel B of Table 3 shows the evolution over time of the total number of loans granted through the different programs. The total number of loans in all three programs is growing over time. This phenomenon is basically explained by two main factors: first, the number of test loans in the primary-credit program has grown over time and more than proportionally (to the total number of loans) in 2014-note that the number of loans in the primary-credit program, net of our measure of the number of test loans, is basically stable over the years at around 1,300 loans. The second factor is that the number of seasonal loans has been increasing consistently over the years under consideration.

Figure 1 plots the monthly total amount lent at the discount window during our sample period. Since the data are volatile, we include in the figure a six-month moving average to highlight any trends present in the data. It is evident in the figure that lending generally increases in the second half of the year. As we will see later, this pattern is present both at the primary-credit and seasonal-credit programs. Aside from those fluctuations, lending seems relatively stable over the five-year period.

\footnotetext{
${ }^{2}$ Relatively speaking, as a source of funding for banks, the discount window is miniscule during normal times (such as the years covered in our sample). For example, total deposits at FDIC-insured institutions in the last quarter of 2014 were close to $\$ 12$ trillion.
} 


\section{Figure 1 Total Discount-Window Lending}

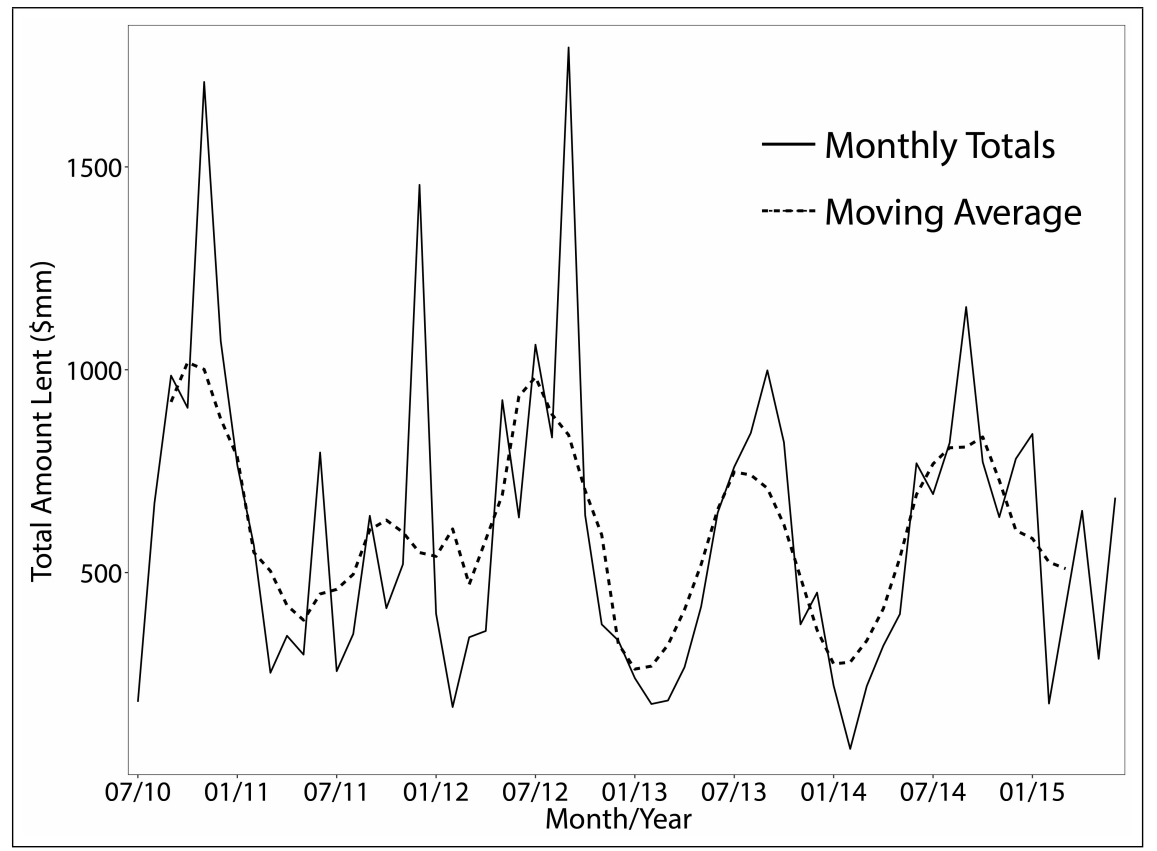

Note: For each month in our sample, we aggregate all loans in that month to generate the monthly series plotted as the solid line. We also compute a symmetric, six-month moving average, which is the smoother dashed line.

Given that now the expectation in financial markets is that information about activity at the discount window will become public after two years, one natural question to ask is whether banks have used the discount window less as a result of this added transparency. To get a sense of this, it would be good to compare the levels of lending during our sample period with lending in previous periods of similar characteristics - mainly, noncrisis periods. While loan-level data are not publicly available for the period before 2007, the Federal Reserve has been publishing for a much longer time the average daily amount of outstanding loans at the discount window in its H.4.1 weekly data release.

Table 4 uses the data from the H.4.1 release to compare the annual average of daily outstanding loans at the three main discount-window programs for the period 2003-07 and for the period 2011-15. We see in the table that the level of discount-window activity is relatively lower 
Table 4 Total Discount-Window Lending Before and After the Crisis

\begin{tabular}{|c|c|c|c|}
\hline Year & $\begin{array}{l}\text { BEFORE THE CRISIS } \\
\text { Average daily loan } \\
\text { amount outstanding }(\$ \mathrm{~mm})\end{array}$ & Year & $\begin{array}{l}\text { AFTER THE CRISIS } \\
\text { Average daily loan } \\
\text { amount outstanding }(\$ \mathrm{~mm})\end{array}$ \\
\hline 2003 & 98.00 & 2011 & 62.058 \\
\hline 2004 & 153.038 & 2012 & 72.442 \\
\hline 2005 & 199.346 & 2013 & 78.654 \\
\hline 2006 & 224.654 & 2014 & 117.585 \\
\hline 2007 & 587.788 & 2015 & 124.673 \\
\hline
\end{tabular}

Note: The annual number is the average of the daily numbers reported for each week of the year in the Federal Reserve H.4.1 Data Release.

in the period after the Dodd-Frank Act. This is consistent with the view that disclosure tends to discourage borrowing (Kleymenova 2016). However, other changes in the financial landscape after the crisis may have also contributed to the reduction in discount-window activity. For example, the high levels of interest-paying excess reserves (Ennis and Wolman 2015) tend to reduce the risk for depository institutions to find themselves short of funds due to unexpected payment shocks. Similarly, more recently, heightened regulatory focus on balance sheet liquidity might be inducing banks to hold liquidity buffers that can also protect them from unexpected late-in-the-day payment shocks. Presumably, then, these liquidity enhancements make banks less likely to need to tap the discount window as a backup source of funding.

A look at more disaggregated data shows (see Table A1 in the Appendix) that both primary and seasonal credit have decreased after the crisis - secondary credit is very small (and volatile) in both periods. Interestingly, after a significant decrease during the crisis, seasonal credit seems to be converging back to numbers common in the precrisis period. Primary credit, instead, has been consistently smaller and decreasing in time after the crisis (see also Table 3 ).

Note, finally, in Table 4 that discount-window lending increased significantly in 2007. In fact, the corresponding amounts for 2008 and 2009 (see Table A1) are an order of magnitude larger than the numbers in Table 4 ( $\$ 32$ billion and $\$ 40$ billion, respectively), and the second half of 2007 was already showing the signs of those forthcoming increases. These "crisis" numbers put in perspective the levels of lending that occur in "normal" times (as in our sample period), which is not zero but relatively moderate. 
Going back to the transactions data, it is also possible to get a sense of the variation in activity across Federal Reserve districts. In Panel A of Table 5, we show the total amount lent by each Reserve Bank over our sample period. The largest lenders in terms of total amount lent are the Atlanta, Chicago, and San Francisco Feds. The San Francisco Fed lent mostly through the primary-credit program, and the Atlanta Fed lent more than half of its total through the seasonal-credit program. Indeed, the Atlanta Fed is the largest lender of seasonal credit among all the Reserve Banks, followed by Minneapolis.

Based on the information on the number of loans granted, as provided in Panel B, it seems that the Chicago and Minneapolis Reserve Banks grant a lot more loans at the seasonal-credit facility than the other Banks, and in particular, Atlanta. This, in turn, implies that the average size of the seasonal-credit loans is much smaller in the case of the Chicago than in the case of Atlanta: the first grants a lot of small seasonal loans, and the second grants fewer loans but larger ones.

Philadelphia, San Francisco, and Chicago are the top providers of secondary credit in terms of total amount lent. While the Atlanta Fed provided a large number of secondary-credit loans (244), all of them were $\$ 1,000$ and, hence, most likely test loans. If we restrict the sample to those loans that are greater than $\$ 10,000$, we see (in the column labeled "w/o") that San Francisco and New York rank at the top in terms of the number of secondary-credit loans granted during the sample period. It should be said, though, that the small sample size makes it particularly hard in this case to draw strong inferences about general patterns.

The largest lender through the primary-credit program (in terms of total amount lent) is the San Francisco Fed. The Chicago Fed made the largest number of loans through this program, but almost half of them were loans that are very likely to have been test loans (for amounts equal or below $\$ 10,000$ dollars). For most of the Reserve Banks, between a third and a half of the primary-credit loans can be safely categorized as test loans.

Perhaps surprisingly, when we restrict the sample to loans greater than $\$ 10,000$ and look at the average size of primary-credit loans across districts (not reported in the table), we see that the Dallas Fed is providing the largest loans on average ( $\$ 6.4$ million), followed by Philadelphia ( $\$ 5.9$ million), and St. Louis ( $\$ 5.6$ million). The New York Fed is fourth (with an average loan amount equal to $\$ 5.5$ million). In principle, since the highest concentration of large banks is in the New York district, one might have expected that the largest discount-window loans were being originated there. That is not the case in our sample period. 

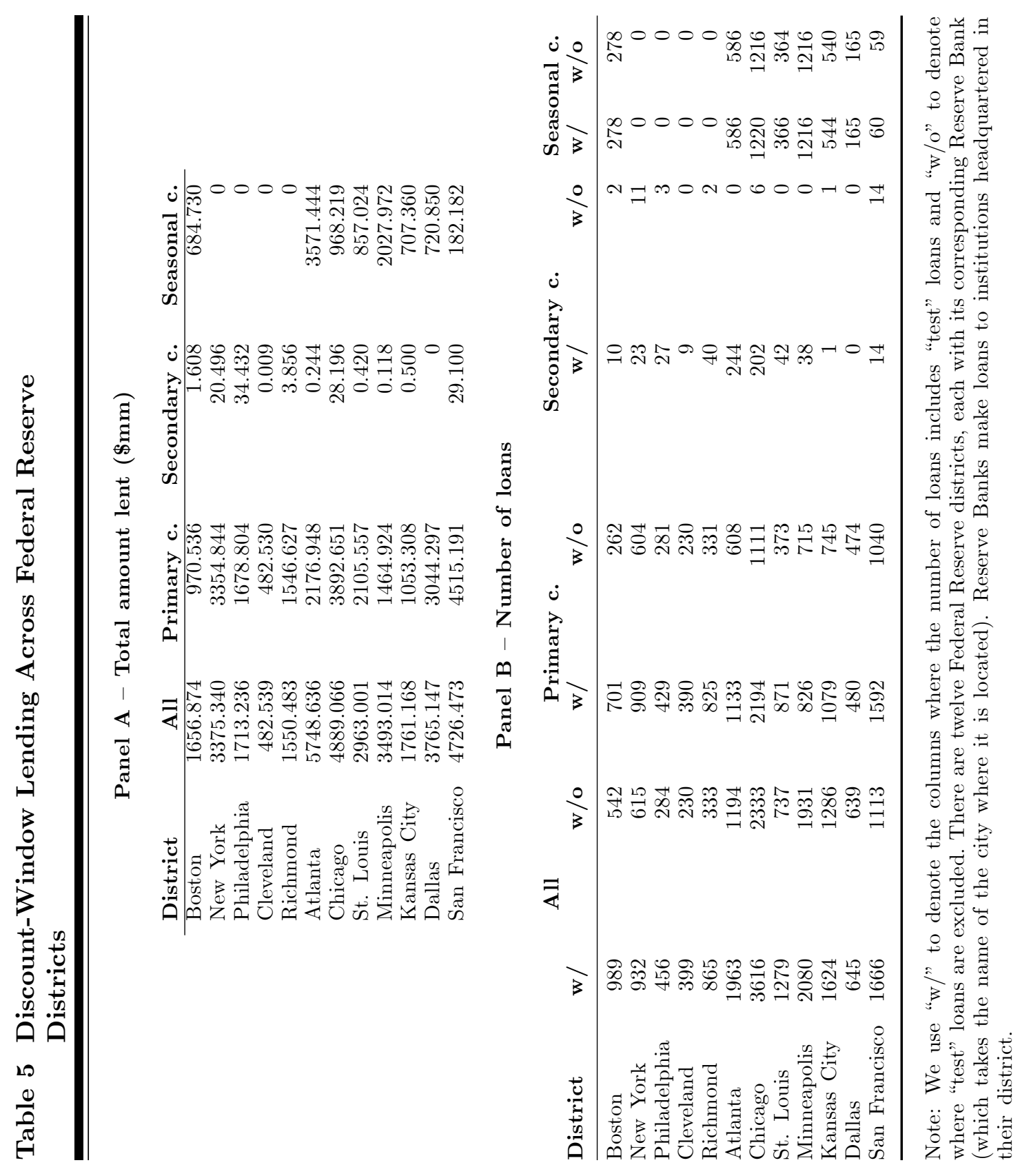
Finally, note (Panel B of Table 5) that there are very few loans of $\$ 10,000$ or less granted by the Dallas Fed (in all three programs). Upon closer inspection of the transactions data, one can see that 264 loans (out of the 645 loans) were for exactly $\$ 100,000$. This suggests that different Reserve Banks may have different practices when it comes to the size of the loans used for testing, with the Dallas Fed perhaps being a Bank that recommends larger test loans than other Feds.

\section{PRIMARY CREDIT}

In this section, we explore further the main characteristic of loans granted through the primary-credit program. We look at the distribution of loan sizes and maturity terms. We also investigate the extent to which lending displays seasonal patterns and, lastly, whether some banks are more prone than others to tap the primary-credit facility (that is, the intensity of use across banks).

Loan sizes: as was discussed in Section 1, the median primarycredit loan is much smaller than the average. This is because the largest loans in our sample were granted through the primary-credit facility, which also made a significant proportion of relatively small loans. Even when we abstract from the majority of the small test loans, as we did in Table 2, we see that the average size of primary-credit loans is four times larger than the median.

Figure 2 plots the distribution of loan sizes for all loans smaller than or equal to $\$ 10$ million. It seems clear from the figure that most loans are in the size range that is below $\$ 5$ million. In fact, during our sample period, 40 percent of all primary-credit loans were $\$ 10,000$ or less, and more than half were $\$ 100,000$ or less. On the other end of the distribution, 10 percent of loans were greater than $\$ 5$ million.

The distribution of loan sizes in Figure 2 appears to be approximately log-normal (with additional concentration of mass at certain amounts). To shed further light on these patterns, we plot in the Appendix (see Figure A1) the distribution of the log size of loan amounts, which should have the shape of a normal distribution if the distribution in Figure 2 was log-normal. While the resulting distribution is relatively symmetric, the figure makes more evident the high concentration of mass around certain specific amounts, such us $\$ 1,000, \$ 10,000$, $\$ 100,000$, and $\$ 1$ million. Some of these spikes in the distribution are likely to be explained by the preponderance of small-amount test loans, but there may also be a tendency from banks to borrow round-number amounts.

To gain some perspective on the financial stakes at play when a bank decides to borrow from the primary-credit program, we calculate 
Figure 2 Distribution of Loan Sizes. Primary Credit

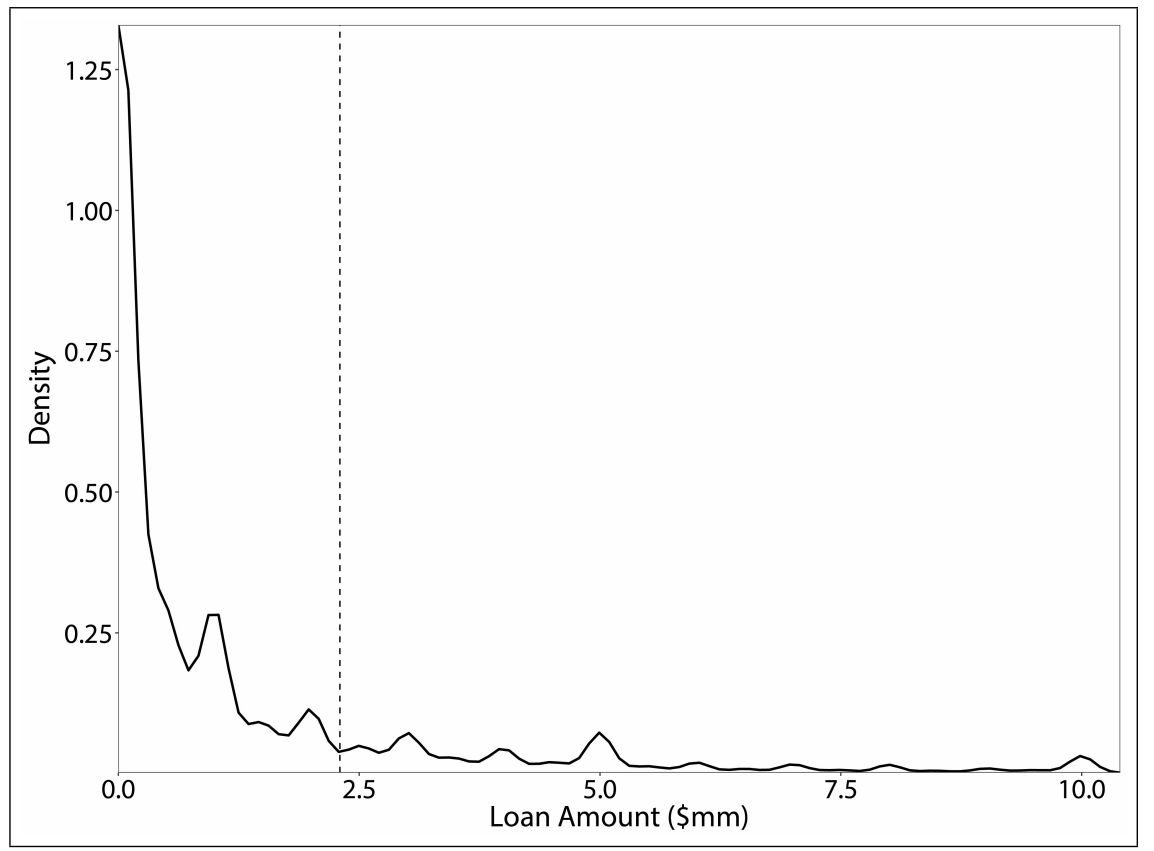

Note: We plot the distribution of loan sizes for loans of $\$ 10$ million or less. We omit loans greater than $\$ 10$ million from the plot to reduce the length of the right tail. We then scaled the distribution by the proportion of loans less than $\$ 10$ million. There are 436 loans that are greater than $\$ 10$ million in the sample. The vertical dashed line represents the mean of all loans ( $\$ 2.3$ million).

the interest expense on a $\$ 10$ million overnight loan at the interest rate relevant for all the primary-credit loans in our sample, 75 basis points. The amount charged is approximately $\$ 200$ in interest payments per day. Given that almost 90 percent of primary-credit loans are overnight loans (see Table 6), we can conclude that a significant portion of the activity at the primary-credit facility constitutes relatively small loans with no significant interest cost for the borrower.

However, there are also some very large primary-credit loans being made in the period under consideration. For example, the largest primary-credit loan in the sample was for $\$ 1.02$ billion and was granted by the St. Louis Fed on Wednesday, November 24, 2010, to First Tennessee Bank, N.A. The term of the loan was two days, which is relatively unusual, as most primary-credit loans are overnight. First Tennessee 
Figure 3 Distribution of Loan Sizes-Evolution Over Time

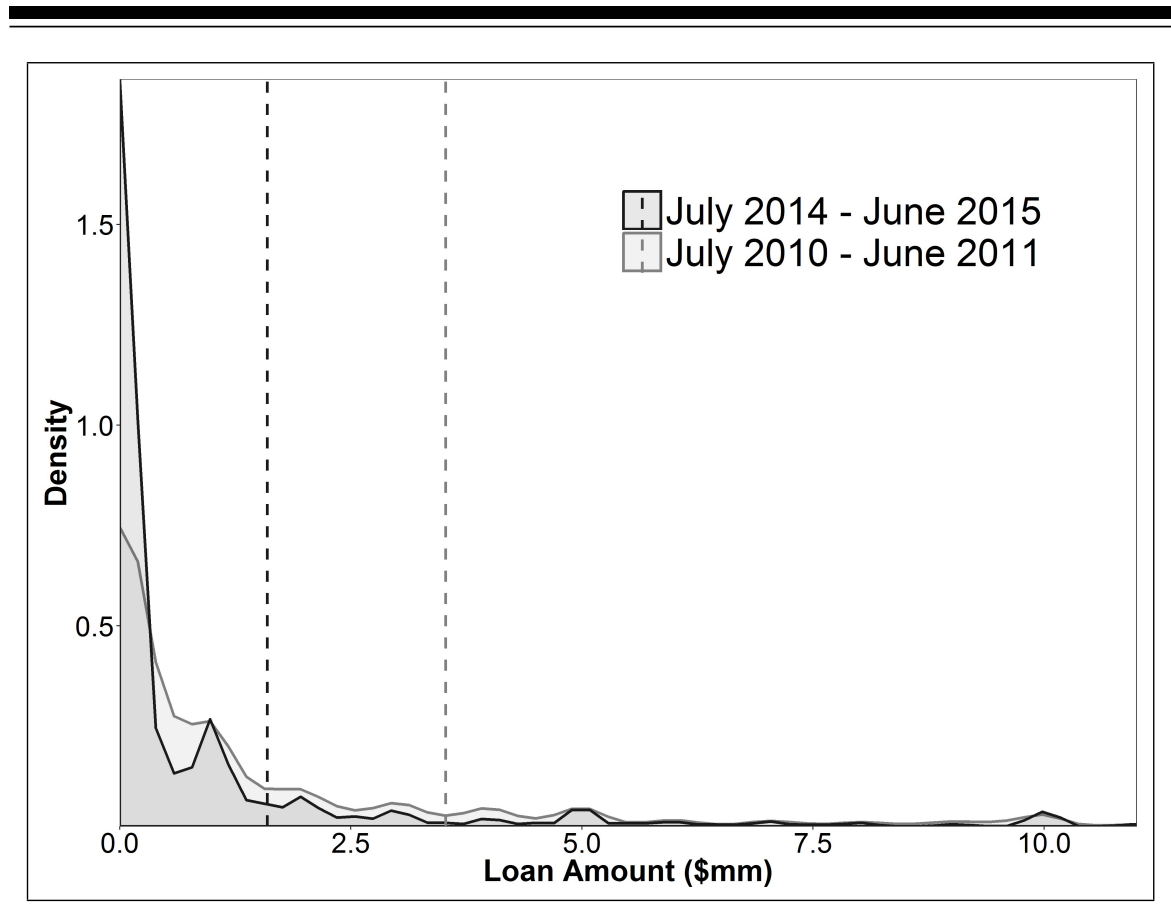

Note: We consider the first and the last twelve-month period in our data. For the period July 2010 to June 2011, we exclude from our density calculations one clear outlier: a loan for (approximately) $\$ 1$ billion (which is ten times larger than the second-largest loan in this subsample). As in Figure 2, we plot only the portion of the distribution that corresponds to loans of $\$ 10$ million or less.

Bank had $\$ 24.5$ billion in assets and $\$ 3.2$ billion total equity as of December 2010, so the discount-window loan was a significant financial transaction for the bank. The second-largest primary-credit loan in the sample was for $\$ 900$ million and was granted by the New York Fed to the New York branch of the Belgian bank KBC on Friday, December 9, 2011. The term of the loan was three days and was repaid at maturity on the following Monday.

Evolution of the distribution over time: As indicated in Table 3, total lending at the primary-credit facility was significantly lower toward the end of our sample period relative to what it was at the beginning. It is also interesting to see that the number of loans increased moderately and, consequently, the mean size of primary-credit loans decreased substantially. 
Figure 3 plots the distribution of loan sizes for the first twelve months in our sample period (from July 2010 to June 2011) and compares it with the distribution of loan sizes for the last twelve months of that period (from July 2014 to June 2015). This confirms the pattern suggested by Table 3: in the later part of our sample period, the proportion of loans that are small is much higher. Figure A2 in the Appendix provides a more complete picture of the evolution of the distribution of loan size over time.

During 2010 and 2011, the US banking system was still recovering from the financial crisis. Furthermore, economic turmoil in Europe at the time impacted the financial condition of some banks in the US (recall that foreign-bank subsidiaries have access to the Fed's discount window). This may partly explain the elevated levels of primary-credit activity during that period and the relatively large size of the average loan. In contrast, by the second half of 2014, the banking system in the US was in much better financial shape, a fact that is likely to have contributed to reducing banks' demand for emergency credit.

Term to maturity: Primary-credit loans are mainly overnight loans. Loans made on a Friday, however, are held for a minimum of three days and are charged interest accordingly (that is, for at least three days). Furthermore, in certain specific situations, loans are granted for longer periods of time. While primary credit is provided relatively automatically ("no questions asked"), when banks request loans of a longer maturity than overnight, some extra administrative oversight may occur.

Table 6 provides a description of the maturity profile of primarycredit loans in our sample. There are a lot of loans in the two- to four-day maturity term. Many of those are associated with holidays and weekends. Of the 962 loans with a three-day maturity term, 955 were granted on a Friday. Similarly, many (but not all) of the four-day loans involved a weekend, preceded or followed by a holiday. 


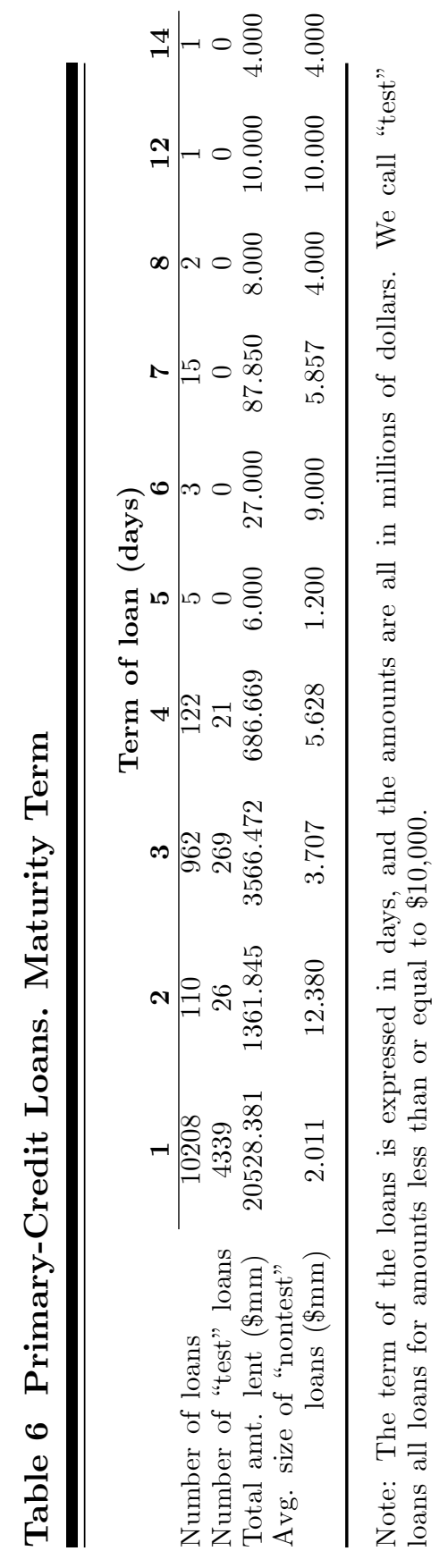


We see in Table 6 that there are a few loans lower than or equal to $\$ 10,000$ and with maturity terms higher than one day. This may be indicative of the fact that not all loans in that size range constitute test loans, in the sense that it seems unlikely that a bank would choose a Friday to conduct a test given that the interest cost is higher than when the test is done with an overnight loan.

The longest maturity term for a primary-credit loan in our sample was a fourteen-day loan granted by the Dallas Fed to First National Bank of Rotan, Texas, in January 2015. The loan was for $\$ 4$ million, which is close to the average amount of all overnight loans greater than $\$ 10,000$ and not much different from many of the other longer-term loans in our sample. Interestingly, the loan was actually paid back early, after nine days.

Of the more than 10,000 primary-credit loans in our sample, only ten of them were paid before maturity. We provide a list of these loans in the Appendix (Table A2). The loans that are paid before maturity tend to be relatively large: the average size is $\$ 4.8$ million, and all but one of them are larger than $\$ 100,000$. Their maturity is not concentrated in any particular term, and it does not appear to be the case that only the longest maturity loans get repaid earlier.

Seasonality: The average amount lent in each month of the year during our sample period seems to increase as the end of the year approaches. Figure 4 shows that after fairly high levels of total borrowing in January, borrowing slows down in February and only gradually increases as the year progresses.

The high level of lending observed in September is partly driven by an event in September 2012 when a bank in Texas took out several loans of a significant amount during that month. This episode is discussed in more detail below. ${ }^{3}$ Even when we remove the large loans to the Texas bank, the month of September exhibits more lending than August and October. In effect, June, September, and December (endof-quarter months) seem to be months where lending tends to increase. We confirm this below in Table 7 .

\footnotetext{
${ }^{3}$ It is important to realize here that the way these numbers are calculated tends to overweight the importance of short-term loans that get rolled over. As an example, if a bank borrows $\$ 100,000$ for two days and another bank takes a loan of $\$ 100,000$ for one day and then another loan of the same amount the following day, the second lending strategy would add up to $\$ 200,000$ of lending, while the first will only count as $\$ 100,000$ toward the total amount lent in that month.
} 


\section{Figure 4 Average Total Amount Lent of Primary Credit in Each Month}

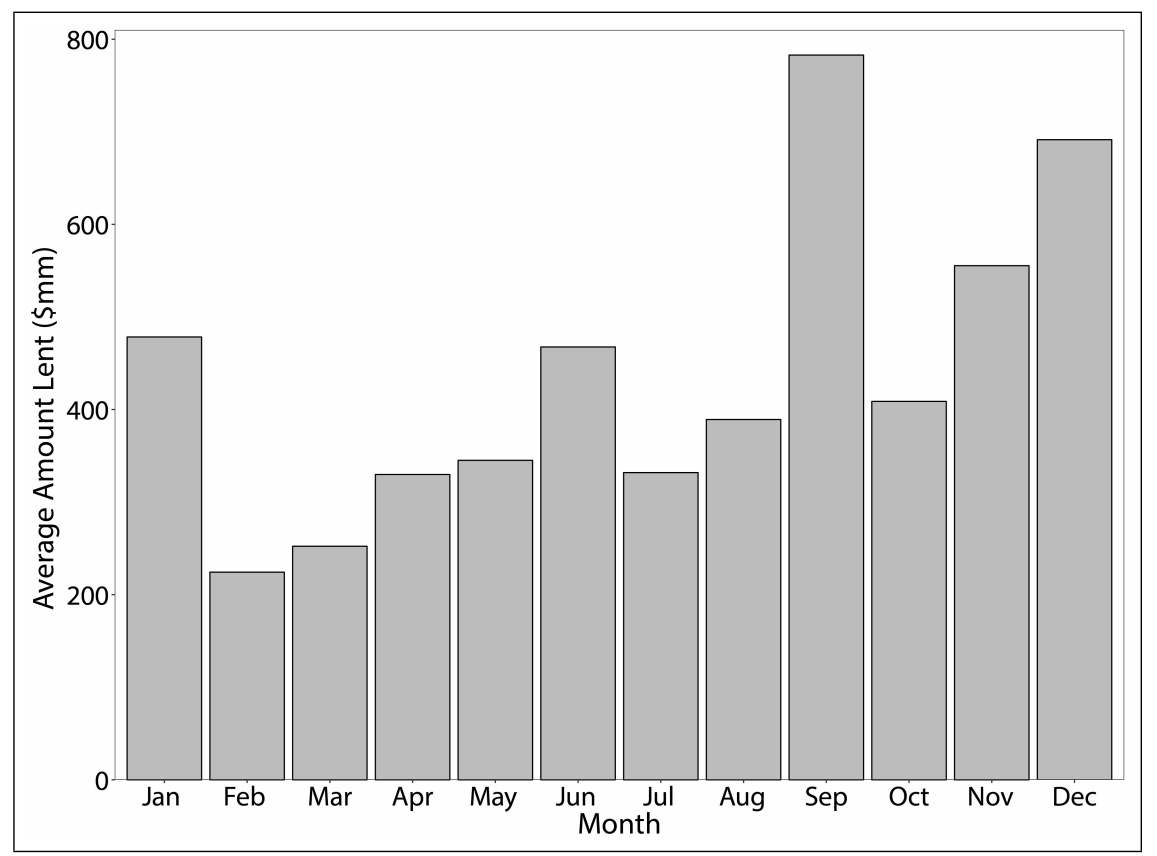

Note: Each month appears five times in our sample period. For each month, we sum the total amount lent during that month and average that amount among the five corresponding totals. That is, for example, for the month of January we sum all the lending done in January in each of the years in our sample and then take the average over the five Januaries in our sample.

Quarterly and monthly frequency: The first row of Table 7 shows how much primary-credit lending takes place during the beginning, middle, and end days of the month. The pattern suggests that lending is higher at the beginning and end of the month and slows down during the days in the middle. A similar pattern arises when we compute the average amount lent in the first, second, and third month of the quarter (second row of Table 7): lending picks up noticeably toward the end of the quarter.

Daily frequency: Table 8 shows the average total number of loans granted in each day of the week during our sample period and the average number of test loans. We see that banks tend to avoid "testing" on Fridays and other special days such as the end of the month, quarter, 
Table 7 Total Amount Lent at Different Times of the Month and the Quarter $(\$ \mathrm{~mm})$

\begin{tabular}{llll}
\hline & & & \\
& Beginning & Middle & End \\
\cline { 2 - 4 } Month & 136.316 & 111.110 & 194.801 \\
Quarter & 387.220 & 378.519 & 548.571 \\
\hline
\end{tabular}

Note: For the monthly calculations, we divide the month into three periods of (approximately) ten days each and call the first ten days the beginning of the month, the next ten days the middle of the month, and the last ten days the end of the month. For the quarterly calculations, the beginning of the quarter is the first month of the quarter, the middle is the second month, and the end is the third month. We calculate the total amount lent in each subperiod, and we report the average across all the corresponding subperiods in the sample.

and year. This makes sense to the extent that conducting a test on a Friday would be more costly.

We also report in Table 8 the total amount lent on average in each of those days (third row) and the average size of loans granted each day that were greater than $\$ 10,000$ (fourth row). The last three columns report similar statistics for the day that corresponds to the end of a month, a quarter, or a year in our sample period.

In general, there is less lending happening on regular Fridays, but the size of the loans are larger on average. Also, the table shows that there is a lot more lending happening on days that are the end of a month, quarter, or year, and the average size of those loans is larger than for other regular weekdays.

Intensity of use: A lot of banks accessed the primary-credit facility during our sample period. Overall, a total of 2,758 different banks (identified by the corresponding ABA number) borrowed at least once from the facility. Of these, 1,756 of them borrowed at least twice, and some banks borrowed over sixty times during our five-year sample. Many of these loans are likely to be tests, of course. For this reason, we also look at intensity of use after restricting our sample to loans greater than $\$ 10,000$. The total number of different banks that borrowed from the facility (at least once) reduces to 1,450 after we restrict our sample to nontest loans.

Figure 5 presents the histogram of the number of times that individual banks borrowed loans for amounts greater than $\$ 10,000$ from the primary-credit facility during our sample period. 
Figure 5 Histogram of the Number of Primary-Credit Loans by Individual Banks

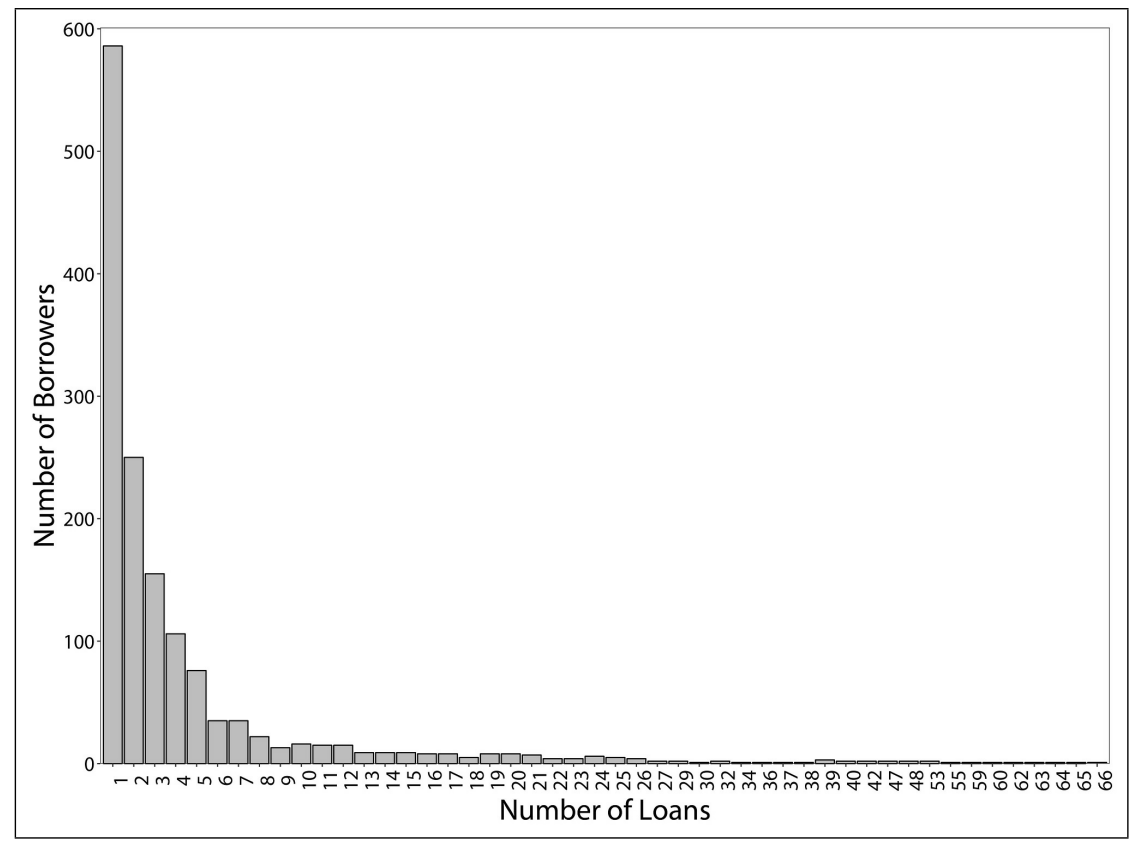

We compute the number of individual nontest transactions (loans greater than $\$ 10,000)$ that each individual bank entered at the primary-credit facility and plot the histogram of these numbers; that is, each bar in the histogram denotes the number of banks that borrow $\mathrm{n}$ amounts of times from the primary-credit facility, with $\mathrm{n}=1,2,3 \ldots$ up to sixty-six, which is the maximum number of nontest primary-credit loans taken by an individual bank in our sample during the fiveyear period under consideration. We identify a bank by its ABA number because it is a more consistent identifier than the bank's name.

We see in the figure that almost 600 banks took one "nontest" loan during the period, but there were also twenty-eight banks that took thirty or more "large" (nontest) loans from the discount-window primary-credit program in the span of five years. In other words, some banks appear to be relatively frequent users of the facility. ${ }^{4}$

\footnotetext{
${ }^{4}$ Even if we restrict attention to loans greater than $\$ 100,000$ (given that it is possible that some Reserve Banks, such as Dallas, ask for test loans of an amount equal to $\$ 100,000)$, the number of banks that borrowed at least thirty loans greater than $\$ 100,000$ in the space of five years is equal to twenty-six.
} 


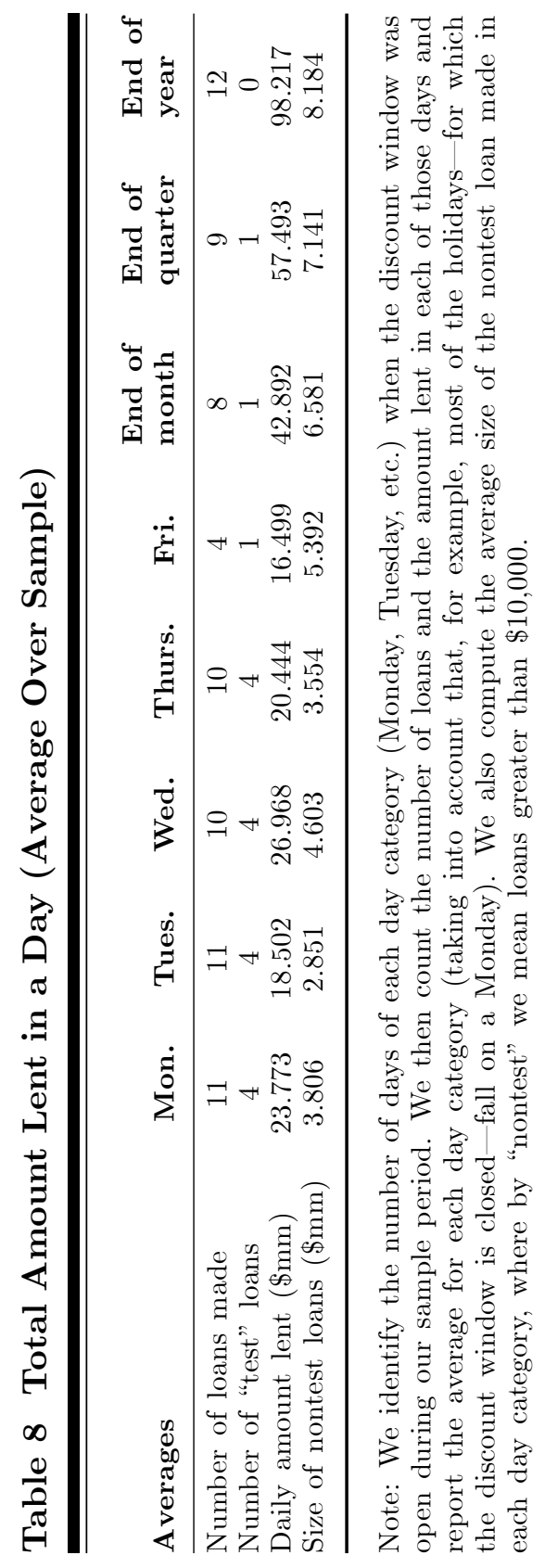


In terms of intensity of use of primary credit, one noticeable case is the situation of Texas Capital Bank, N.A., which in September 2012 borrowed significant amounts overnight for several consecutive days from the Dallas Fed, with balances as high as $\$ 250$ million (on September 5). Between October 2011 and January 2013, Texas Capital Bank borrowed nineteen times, and in ten of those instances the loans were for an amount larger $\$ 100$ million (See Table A3 in the Appendix for details).

While the calculations used to produce Figure 5 can be informative, they are not able to reveal some particularly relevant details of the lending patterns observed in the data. For example, some institutions may be rolling over a loan for several days with each loan counted as a new loan while, in a sense, the credit event could be considered to be just one event. Other institutions, instead, may be "repeat users" in that they periodically take an overnight loan and repay it at maturity (and only take another loan after some time). Additionally, some institutions may be repeat users, yet of loans of a very small amount.

There are, of course, many ways to present information that speaks to these issues. We pursue several ones here. For example, we compute the number of primary-credit loans that were the result of a rollover of a previous loan. There were 1,731 loans that were followed by a loan by the same institution on the day that the first loan matured. This amounts to approximately 15 percent of all primary-credit loans in our sample.

Of the loans that were rolled over, only 302 were rolled over for the same dollar amount. Figure 6 plots the amount of the original loan and the amount of the subsequent loan (the rolled-over amount) to get a sense of whether or not loans get rolled over to smaller amounts (as a way to pay down the loan gradually). To make the figure readable, we only plot those loans that were $\$ 20$ million or less. ${ }^{5}$

The figure shows that there is no clear pattern: some loans get rolled over into larger amounts, some into smaller amounts, and some into the same amount (these last are represented by the dots that fall exactly over the forty-five-degree line plotted in the figure). ${ }^{6}$

Of the 11,429 primary-credit loans, 9,000 of them were loans that were not followed by another loan from the same institution on the maturity day (that is, they were not rolled over). Of these loans, 4,650 were loans of an amount less than or equal to $\$ 10,000$. Given that, in

\footnotetext{
${ }^{5}$ Note also that loans that were initially larger than $\$ 20$ million but were rolled over into amounts smaller than $\$ 20$ million do not appear in the figure.

${ }^{6}$ We looked at larger loans than $\$ 20$ million, and there is no indication that larger loans produce a more definitive pattern.
} 


\section{Figure 6 Rollovers in Primary Credit}

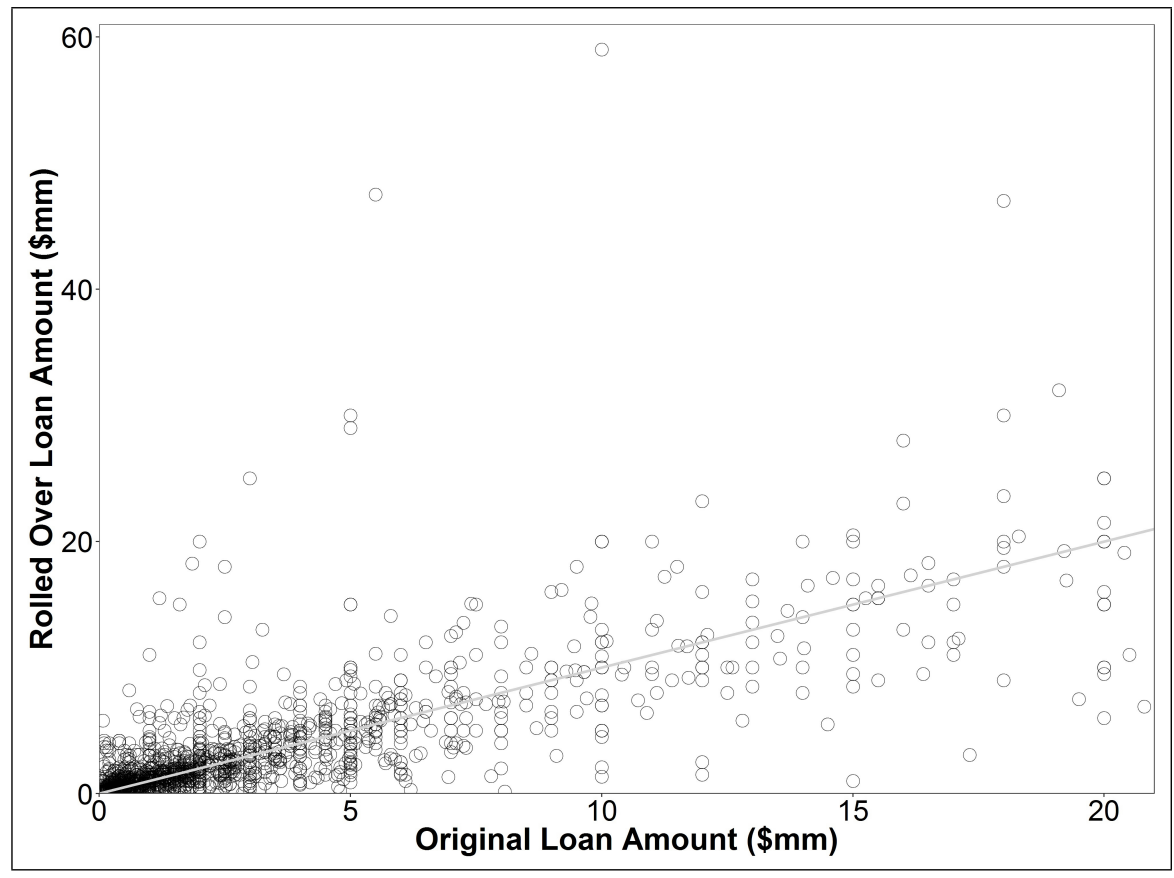

Note: The solid diagonal line is the forty-five-degree line. We only consider consecutive loans that were originally for an amount less than or equal to $\$ 20$ million.

total, there were 4,655 primary-credit loans of an amount lower than or equal to $\$ 10,000$, that tells us most of those smaller loans, predominantly "test" loans, were not followed by a consecutive loan.

If we call a credit event a sequence of consecutive loans taken by a bank where one loan is followed by another loan (of potentially a different amount) at the time of the maturity of the previous loan, then there were 350 events involving one rollover (see Appendix), 146 events involving two rollovers, and there are events of all numbers of rollovers up to sixteen, the maximum observed in our sample (only one event involved sixteen consecutive loan rollovers).

The average size of the loans that get rolled over at least once is $\$ 4.7$ million - somewhat larger than the average for all primary-credit loans with amounts greater than $\$ 10,000$, which is equal to $\$ 3.8$ million, as reported in Table 2. This indicates that banks that end up rolling over primary-credit loans tend to borrow larger amounts. 
We also look at situations where a bank takes a loan that we can consider an isolated situation, in the sense that the same bank does not take a loan in the two months around the loan in question (one month prior and one month after). The number of isolated loans identified this way is 7,078 , but presumably many of them were taken as test loans. Indeed, only 2,871 of these isolated loans were for an amount greater than $\$ 10,000$. This means that within the subsample of loans for amounts greater than $\$ 10,000,42$ percent of them were isolated. When we look at this subsample of loans (i.e., loans that are greater than $\$ 10,000$ and isolated), the average size was $\$ 3.7$ million, which is similar to the average size of all loans greater than $\$ 10,000$ (Table 2). In other words, isolated loans that are unlikely to be test loans do not tend to be much different in size than other nontest loans.

\section{SECONDARY CREDIT}

Secondary credit is used much less often than primary credit. There are 650 loans in our five-year sample, of which only thirty-nine are greater than $\$ 10,000$. Virtually all secondary-credit loans were overnight loans. The volume in the secondary-credit program has been trending down over the years under consideration, with the total amount lent and the number of loans both decreasing over time (see Table 3 ).

The number of test loans has probably been decreasing as a result of banks moving out of the "poorly capitalized" category, either by becoming eligible for primary credit - as banks (and the economy) exit the crisis state - or by exiting the industry (through mergers or liquidations). Similarly, the intensity of use of the secondary-credit program, beyond just testing, is also likely to be strongly influenced by prevailing financial conditions: as those improved over the years in the sample period, usage declined.

Loan Sizes: In general, secondary-credit loans tend to be smaller than primary-credit loans. The largest loan at the secondary-credit facility during our sample period is much smaller than the largest primary-credit loan ( $\$ 17$ million and $\$ 1$ billion, respectively). Except for a loan granted by the Philadelphia Fed to Nova Bank in December 2010 for $\$ 17$ million, all other secondary-credit loans in our sample were under $\$ 10$ million in value.

This pattern is stronger toward the later part of our sample period. Indeed, since the end of 2012, there has been very little lending of significant amounts at the secondary-credit program. If we consider only larger loans, using a $\$ 1$ million threshold, then there was only one loan at or above that amount in 2013, three in 2014, and again only one in the first half of 2015. For the whole sample, only twenty-nine 
Table 9 Secondary-Credit Loans. Maturity Term

\begin{tabular}{llllll}
\hline & \multicolumn{5}{c}{ Term of loan (days) } \\
& \multicolumn{1}{c}{$\mathbf{2}$} & $\mathbf{2}$ & $\mathbf{3}$ & $\mathbf{4}$ \\
\cline { 2 - 6 } Number of loans & 587 & 4 & 48 & 11 \\
Number of "test" loans & 558 & 3 & 43 & 7 \\
Total amount lent (\$mm) & 73.249 & 17.003 & 6.010 & 22.716 \\
Average size of "nontest" loans $(\$ \mathrm{~mm})$ & 2.489 & 17.000 & 1.180 & 5.675 \\
\hline
\end{tabular}

Note: The term of the loans is expressed in days, and the quantities are all in millions of dollars.

loans were for amounts greater than or equal to $\$ 1$ million. Clearly, secondary credit is used in a meaningful way outside crisis periods only in rare occasions.

Term to maturity: Most secondary-credit loans have a one- or three-day maturity term (and all the three-day loans were taken on Fridays). Contrary to primary credit, there are no secondary-credit loans of longer maturity than four days (see Table 9) and all four-day loans were made on Fridays followed by a holiday. Potentially, the extra scrutiny by loan officers at Reserve Banks, and the fact that the financial institution seeking the loan is not in obviously sound financial condition, drives this pattern of low maximum maturity length.

When reading Table 9, it is worth noting that there are only four secondary-credit loans of two-day maturity (middle column in the table), of which three of them are for $\$ 1,000$, and one of them is for $\$ 17$ million. This fact drives the high average value of loans of the two-day maturity term but it seems reasonable to attribute the anomaly to the small sample size.

The $\$ 17$ million two-day loan is unusual in that it is the only secondary-credit loan in our sample that was charged an interest rate higher than the standard 125 basis points (that is, fifty basis points higher than the primary-credit rate). The loan was granted by the Philadelphia Fed to Nova Bank, of Berwyn, Pennsylvania, on December 28,2010 , and the interest rate charged was 6.25 percent. Interestingly, this loan was a rollover loan from a loan of the same amount granted for four days on December 24, 2010, at the standard interest rate of 125 basis points. There are no other loans to Nova Bank around that time, which suggests that the bank paid the loan in full on December $30,2010 .^{7}$

\footnotetext{
${ }^{7}$ On Friday, October 26, 2012, the Pennsylvania Department of Banking and Securities closed NOVA Bank, and the FDIC was named receiver.
} 
Figure 7 Average Total Amount Lent of Secondary Credit in Each Month

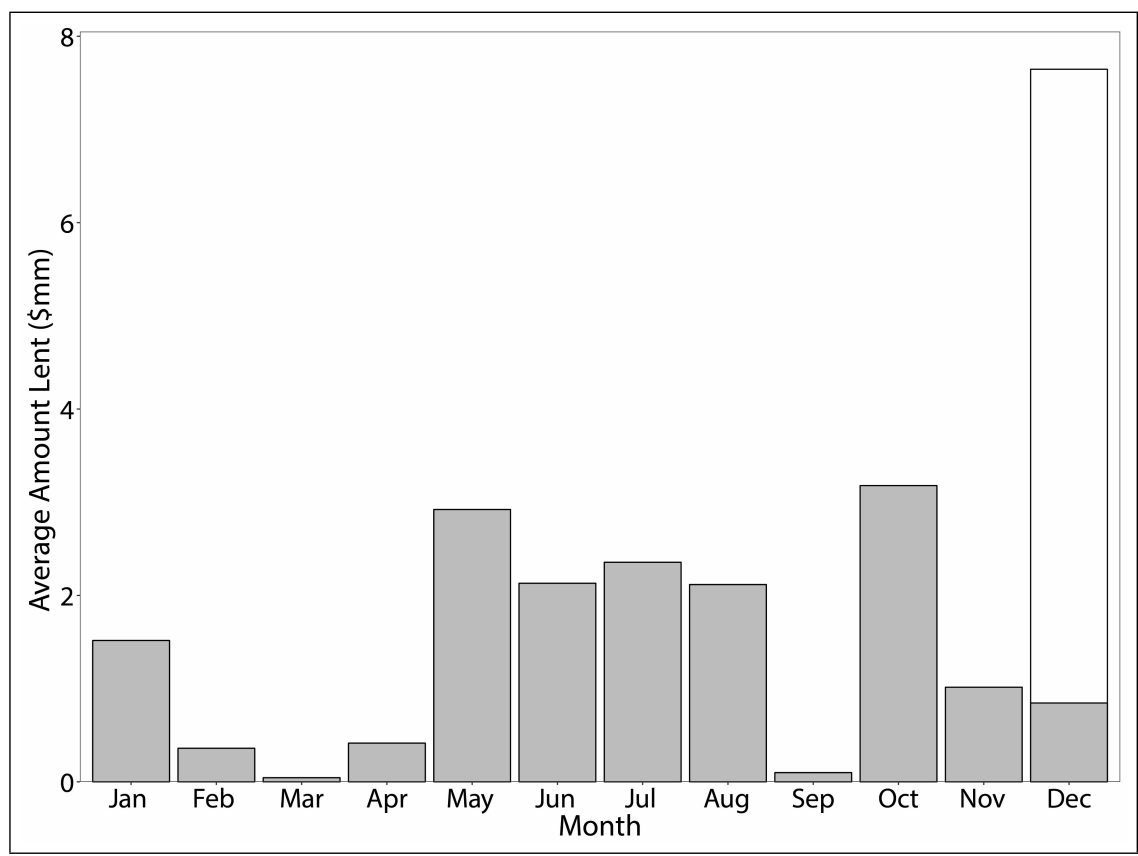

Note: This figure is constructed in the same manner as Figure 4. Each month appears five times in our sample period. For each month, we sum the total amount lent during that month and average that amount among the five corresponding totals. That is, for example, for the month of January, we sum all the lending done in January in each of the years in our sample and then take the average over the five Januaries in our sample. For the month of December, the grey bar represents the average after we exclude the two large loans to Nova Bank in December 2010. The white bar is the average including those two large loans.

The initial loan for $\$ 17$ million to Nova Bank on December 24, 2010 , is also responsible for the high average size of the four-day loan category (see last column of Table 9 ). Excluding that loan, the average four-day loan size is much lower ( $\$ 1.9$ million). Here, again, the small sample size is a significant limiting factor, but it is worth pointing out that this amount is smaller than the average size for all overnight secondary-credit loans ( $\$ 2.489$ million).

Seasonality: Figure 7 shows that secondary credit is concentrated around the middle of the year, with activity being very moderate in the initial months of the year. The December average is heavily influenced 
Table 10 Total Amount Lent at Different Times of the Month and the Quarter

\begin{tabular}{llll}
\hline & & & \\
& Beginning & Middle & End \\
Month & 0.464 & 0.384 & 1.149 \\
Quarter & 1.866 & 1.603 & 2.479 \\
\hline
\end{tabular}

Note: We use the same methodology as used in the construction of Table 7.

by the large loans to Nova Bank in December 2010. After excluding these two loans, the average total amount lent in December at the secondary-credit program is similar to the average level for November and relatively small compared with the middle months of the year. The sensitivity of the December average to the exclusion/inclusion of two loans, however, underscores the fact that the sample for secondary credit is relatively small and, as a result, idiosyncratic events may be biasing some of the statistics computed here.

Just for completeness, Table 10 shows the average level of lending at the secondary-credit program at the beginning, middle, and end of the month and of the quarter (to compare it with Table 7 ). The pattern shows that lending tends to increase at the end of the month and the quarter.

We do not compute a table comparable to Table 8 in the primarycredit section because the subsamples needed to deal with daily patterns (given the presence of test loans) are too small to draw any meaningful inferences. For computing total amounts lent, the test loans play very little role: for example, the 611 test loans (equal to or lower than $\$ 10,000)$ at the secondary-credit program account for $\$ 1.2$ million of the total $\$ 119$ million lent over the sample period (see Table 1). Effectively, then, the total amounts lent reflect the thirty-nine nontest loans in the sample. As we split the sample into subsamples, the number of (nontest) loans in each category becomes too small to make any reliable inference.

\section{SEASONAL CREDIT}

Even though seasonal credit presents a strong annual seasonal pattern, it is clearly discernable from Figure 8 that there has been an upward trend in the total amount lent over the years of our sample. This is also evident in Table 3. Of course, the strong seasonal pattern is not surprising given the objective of this program: to provide ample access 
Figure 8 Total Monthly Seasonal Credit (\$ million)

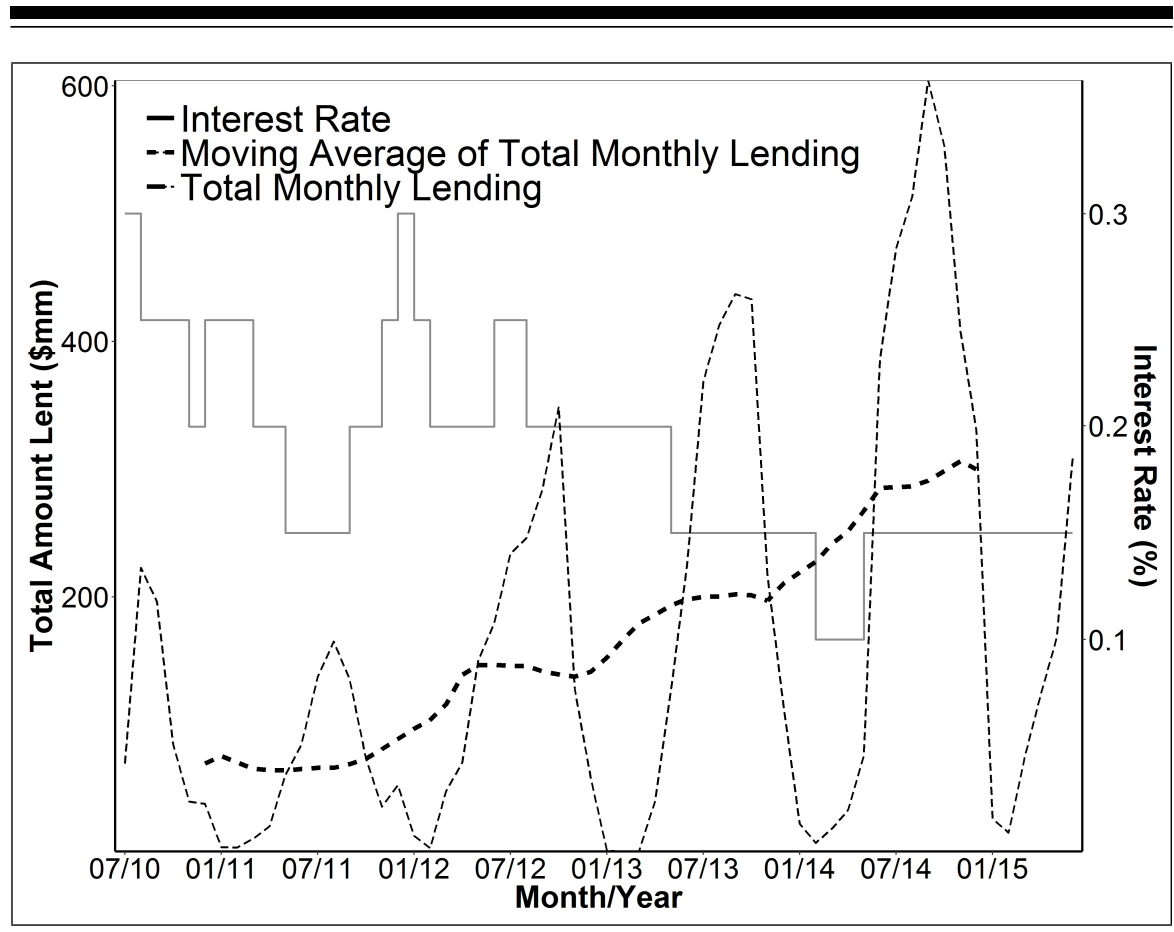

Note: For each month in our sample, we aggregate all loans in that month to generate the monthly time series plotted as the lighter dashed line. We also compute a symmetric, twelve-month moving average, which is the darker dashed line. We overlay the most frequent (discount window) interest rate in the period as the solid line.

to credit to smaller institutions with a predictable (and demonstrable) seasonal pattern in their funding needs.

We included in the figure the interest rate charged for seasonal credit. The rate is calculated as an average of market rates, and it has fluctuated over the years while exhibiting a moderate downward trend. It may be the case that the gradual decrease in the cost of borrowing over the sample period is partly responsible for the (also gradual) increase in lending shown in the figure (although, of course, the cost of other sources of funding probably move together with market rates as well, making those other sources of funding also more attractive).

Loan Sizes: The distribution of loan sizes is plotted in Figure 9. As we know from Table 2, the median size of seasonal-credit nontest loans is similar to the median for primary-credit nontest loans, but the 
Figure 9 Distribution of Loan Sizes. Seasonal Credit

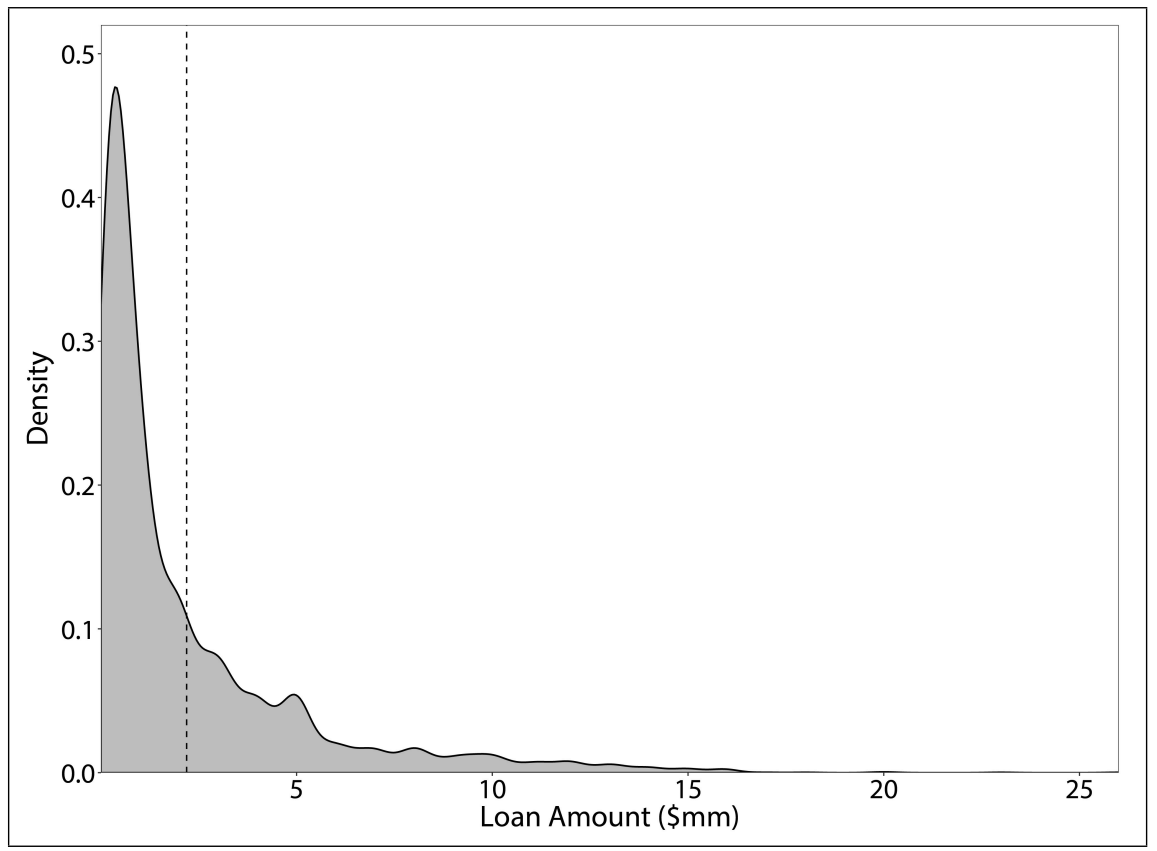

Note: We plot the distribution of loan sizes for all seasonal-credit loans in the sample. The dotted vertical line is the mean.

maximum loan amount is much smaller. As a result, the distribution shows more density in intermediate values, such as loans between $\$ 1$ million and $\$ 10$ million. Since seasonal credit is not provided at a penalty interest rate, the nature of its usage is likely to be very different than for primary credit, with midsize loans being more common (as reflected in the distribution of loan sizes).

Testing also seems less common in the case of seasonal credit. In fact, there are no seasonal-credit loans in our sample for an amount equal to or less than $\$ 1,000$ and eleven loans for an amount between $\$ 1,000$ and $\$ 10,000$. This is of course in sharp contrast with the patterns observed in primary and secondary credit where a large proportion of the loans fell within that range of very small amounts.

Term to maturity: Aside from the difference in the distribution of loan sizes between primary, secondary, and seasonal credit, the maturity of seasonal-credit loans is also much less concentrated around 
Figure 10 Seasonal Credit Loans. Maturity Term

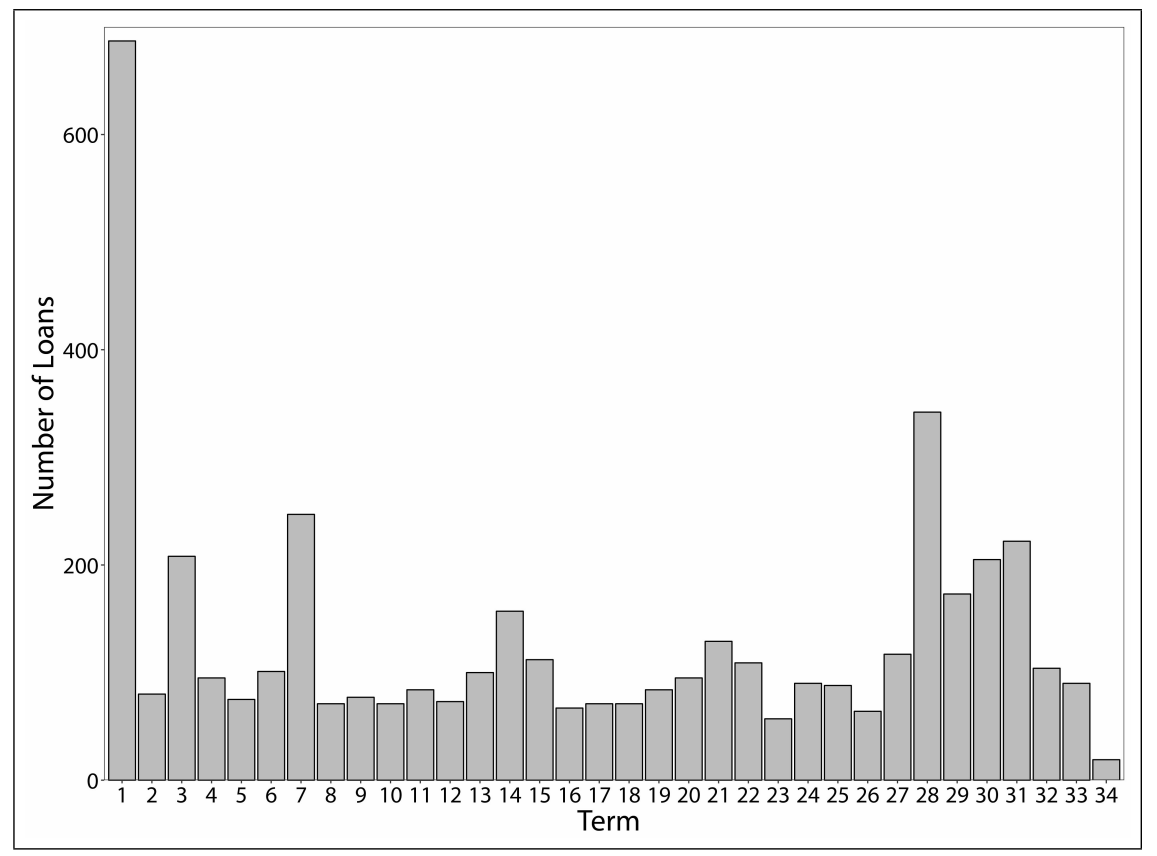

Note: We compute the number of loans of each maturity term from one day (overnight) to thirty-four days, the maximum maturity observed in the sample, and we plot the histogram of the resulting data.

short periods (overnight and three days) than the maturity term of primary- and secondary-credit loans.

Figure 10 presents a histogram of the maturity term of seasonalcredit loans in our sample. Interestingly, loans that are approximately a month long tend to be relatively common among this class of loans. But this relative concentration does not mean that other maturities are not used. In fact, there are many loans for each of the maturity terms in the range between one and thirty-four days. It is still the case, though, that overnight loans are the most common in this subsample, representing 15 percent of the total.

Seasonality: As a complement to Figure 8, in Figure 11 we plot the average amount of seasonal credit provided during each month of the year. The seasonal pattern at the annual frequency is again evident in this figure, with the amount of seasonal credit increasing during the second half of the year and being minimal during the winter months 
Figure 11 Average Total Amount Lent of Seasonal Credit in Each Month

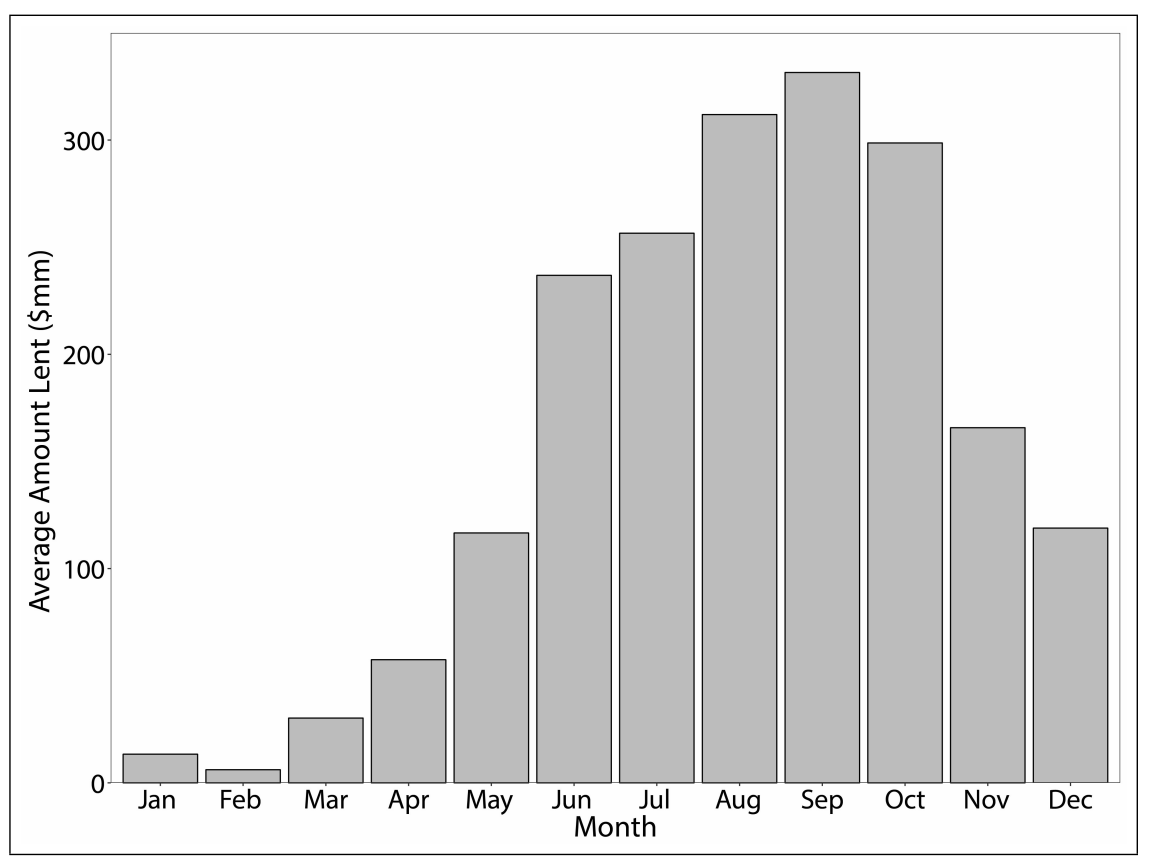

Note: See note for Figure 4.

of January and February. While one might suspect that some of this credit follows the agricultural cycle, it is interesting to note that some of the Reserve Banks in agricultural areas, such as St. Louis and Kansas City, are not large providers of seasonal credit (see Table 5).

\section{COLLATERAL}

Depository institutions can choose to enter credit agreements with their respective Reserve Banks, allowing them to borrow from the discount window if they need to do so at some point. Not all institutions enter credit agreements with their Reserve Bank. When they do, as part of such agreements, depository institutions pledge collateral with Reserve Banks, a process that requires the submission of all the relevant information that would allow loan officers at Reserve Banks to assess the value of the corresponding collateral. Many institutions do not take any loans from the discount window in a given period of time even 
when they have an outstanding credit agreement and potentially large amounts of pledged collateral.

Our data only include collateral information as of the time when a bank actually takes a loan from the discount window. In that sense, the information about pledged collateral in our dataset is not comprehensive. To be more specific, for each loan in the sample, the dataset includes information on the value and composition of the collateral available to the borrower with the corresponding Reserve Bank at the time of the loan. The reported value of collateral is adjusted using the appropriate margins (haircuts) so that, in principle, the borrower could receive a loan for the total amount of the reported collateral.

To get a sense of how collateral is being used in these credit relationships, we look at the average composition of the collateral and the level of utilization (how much lending actually occurs relative to the total amount of collateral available). For this latter calculation, we use the total amount of loans outstanding, including the new loan, which is also reported in our data. The collateral pledged at the discount window can be used in any of the discount-window programs so, for example, a bank can take a loan at the primary-credit program and another loan, simultaneously, at the seasonal-credit program. The reported amount of collateral in our dataset is usable in both types of loans.

None of the banks that took a secondary-credit loan during our sample period had any other outstanding loans from the discount window. Eligibility criteria for borrowing at the seasonal credit porgram generally rule out secondary-credit institutions. For those banks taking loans at the primary-credit program, instead, having loans outstanding is more common but still not very prevalent.

The situation is much different for those banks taking seasonalcredit loans, as more than 40 percent of those banks have loans outstanding at the time of taking the loan reported in our dataset. While most of the outstanding loans are previous seasonal-credit loans, we also verified that some banks were borrowing simultaneously from the primary and seasonal programs during our sample period.

Collateral composition. The composition of collateral varies systematically across credit programs, as reflected in Table 11. For primary-credit loans, almost 50 percent of the collateral is accounted for by commercial and consumer loans, with high-quality securities such as US Treasuries and agency debt and mortgage-backed securities taking roughly another 20 percent of the total. Loans granted under the secondary-credit program, instead, have almost 60 percent of the collateral in the form of commercial real estate (CRE) loans. Finally, 
Table 11 Type of Collateral (as a Proportion of Total)

\begin{tabular}{llll}
\hline Type of collateral & $\begin{array}{l}\text { Primary } \\
\text { credit }\end{array}$ & $\begin{array}{l}\text { Secondary } \\
\text { credit }\end{array}$ & $\begin{array}{l}\text { Seasonal } \\
\text { credit }\end{array}$ \\
\hline Commercial loans & 0.277 & 0.135 & 0.422 \\
Consumer loans & 0.199 & 0.046 & 0.002 \\
CRE loans & 0.069 & 0.585 & 0.281 \\
US Treasury/Agency securities & 0.067 & 0.070 & 0.091 \\
Agency MBS & 0.123 & 0.057 & 0.092 \\
ABS & 0.083 & 0.039 & 0.000 \\
Other & 0.182 & 0.068 & 0.112 \\
\hline
\end{tabular}

Note: For each individual loan taken by a bank, the data include the total amount of collateral available to the borrowing bank and its composition. We aggregate across all loans in our dataset and compute the proportion of each collateral component. There are other categories of collateral not reported in the table and for which the proportions were relatively small. These categories are all aggregated under the label "other." Note that if a bank takes several loans, its collateral is counted multiple times in the aggregation, one time for each time that the bank took a loan.

the collateral of banks taking loans in the seasonal-credit program is mainly composed of commercial loans and CRE loans.

Collateral utilization. We measure collateral utilization as the ratio of total outstanding loans for a given bank and its total collateral pledged with the corresponding Reserve Bank. To understand collateral utilization, it is important to keep in mind that the large proportion of test loans in the primary- and secondary-credit programs, by their nature, tend to use a very low proportion of the collateral available to the borrowing bank.

For primary credit, we concentrate attention on loans that are greater than $\$ 1$ million, since the predominance of test loans can be expected to be very low at those levels of borrowing. Figure 12 shows the level of utilization in the vertical axis and the amount of outstanding loans in the horizontal axis (we plot outstanding amounts up to $\$ 100$ million to make the figure more readable, but the pattern is similar for all loans over $\$ 1$ million). ${ }^{8}$ We can see from the figure that (contrary to what might be expected) there are a lot of large primarycredit loans that use a significant proportion of the collateral available

\footnotetext{
${ }^{8}$ The amount of outstanding loans includes the amount of the loans for which the data are being reported. For this reason, the amount of outstanding loans is always greater than $\$ 1$ million in the figure. Since, for this restricted subsample, only thirtythree out of 2,829 loans were made when previous loans to the borrowing bank were outstanding, the figure basically reflects the utilization ratio calculated using the amount of the current loan.
} 
Figure 12 Collateral Utilization Ratio. Primary Credit

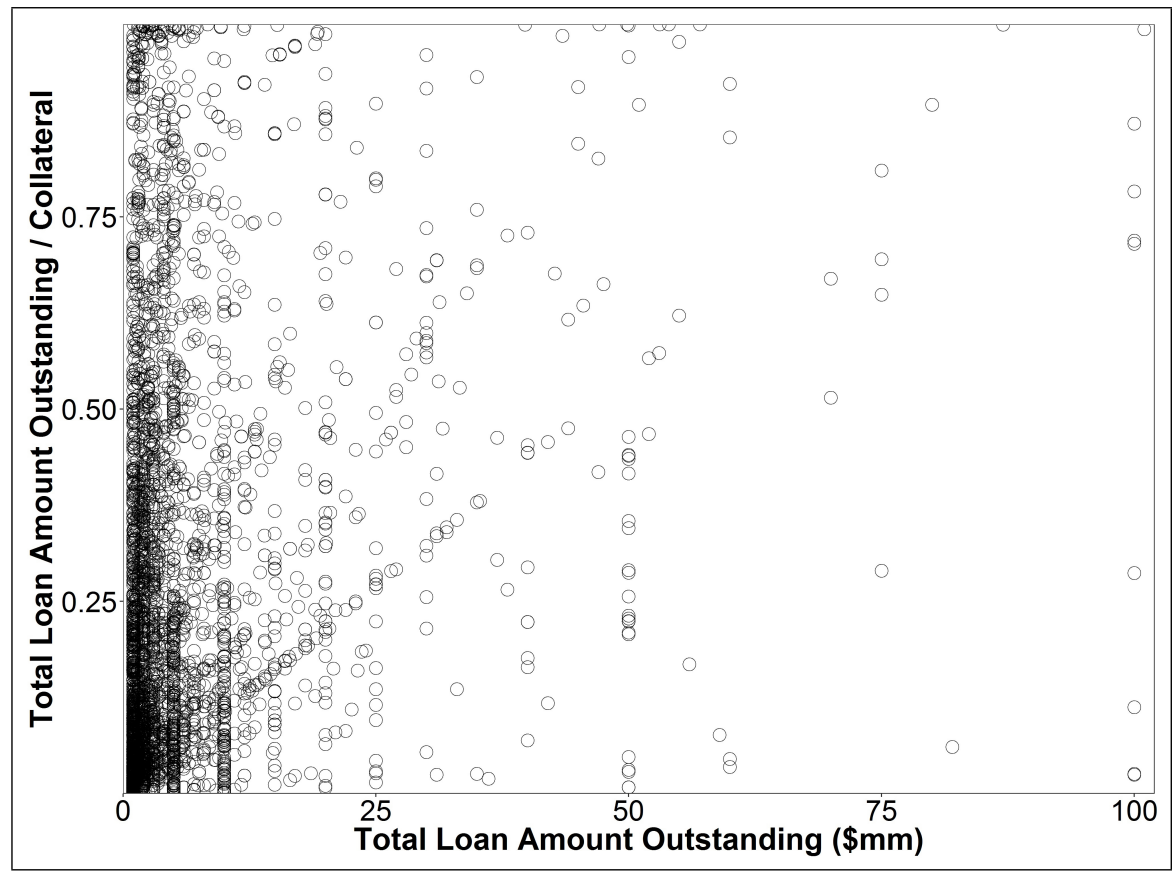

Note: We consider loans at the primary-credit program that, added to the outstanding loans, sum to an amount between $\$ 1$ million and $\$ 100$ million. For each loan, we compute the ratio of the total loan amount outstanding and the total collateral available to the borrower. For each loan, then, we plot the level of utilization on the vertical axis and the outstanding loan amount on the horizontal axis.

to the borrowing bank. Smaller loans also can have relatively high utilization ratios. Furthermore, the figure suggests that there is no strong correlation between the size of the loan and the level of collateral utilization.

For secondary credit, we restrict attention to loans greater than $\$ 10,000$, which in our sample amount to a total of thirty-nine loans. Of those thirty-nine loans, nineteen of them used more than half of the collateral available to the borrower. Collateral utilization for the thirty-nine loans is not concentrated in any particular value and instead is (roughly) evenly spread in the unit interval.

Just as with primary-credit loans, for secondary-credit loans there is no indication of a tight correlation between size of the loans and 


\section{Figure 13 Distribution of Collateral Utilization Ratio. Seasonal Credit}

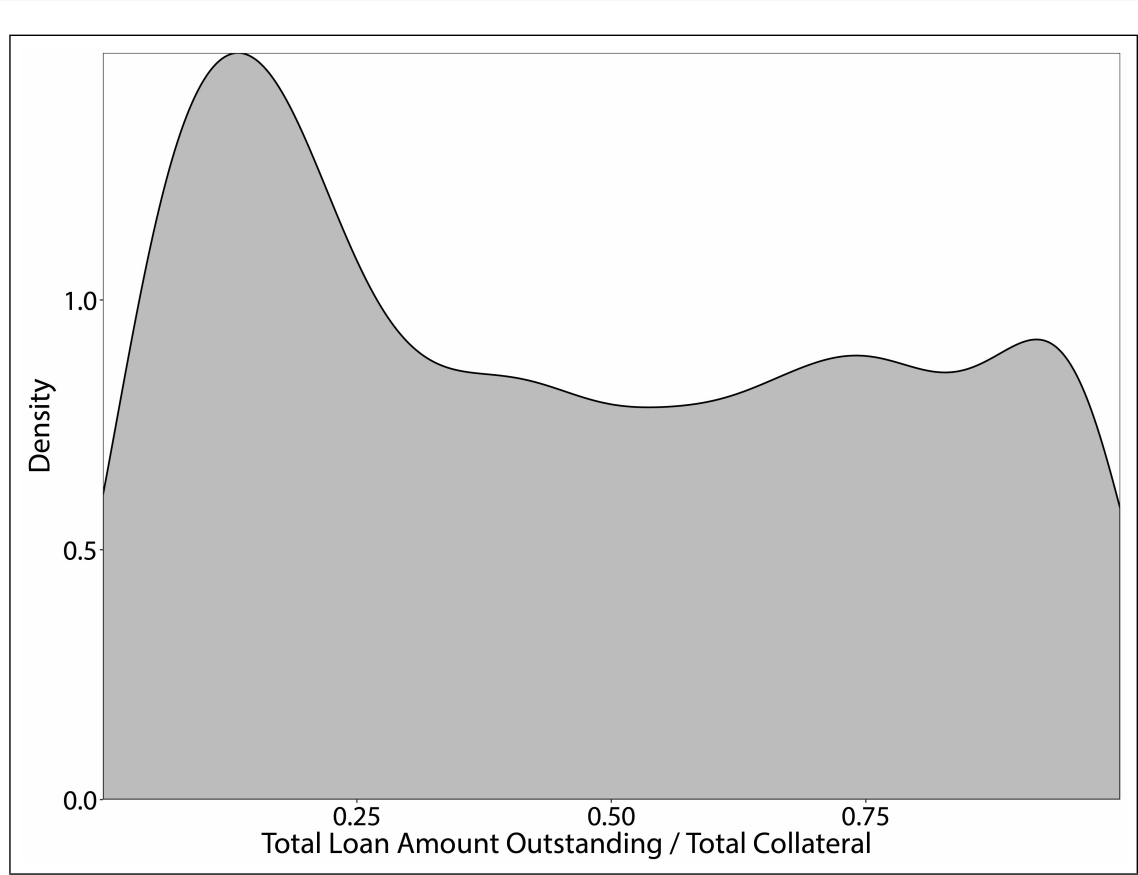

Note: For each loan, we compute the ratio of the total loan amount outstanding and the total collateral available to the borrower.

their collateral utilization. The two largest loans in this subsample of thirty-nine loans - those made to Nova Bank in 2010 for $\$ 17$ million each-have a collateral utilization ratios of 55 percent. On the upper end of the utilization margin (for loans greater than $\$ 10,000$ ), there are three loans with utilization ratio greater than 90 percent.

For seasonal credit, collateral utilization is spread (roughly) evenly over values between zero and one. Figure 13 shows the density of the collateral utilization ratio for seasonal-credit loans. Since test loans seem to be much less common in the seasonal-credit program, we include all loans in the figure. For seasonal credit, it is critical to measure utilization using outstanding loan amounts, given that in most cases these loan amounts can be much higher than the amount of the new individual loan that originates the reporting. 


\section{CONCLUSION}

In the five years of now-available discount-window transactions data, from mid-2010 to mid-2015, the Federal Reserve made over 16,000 loans for a total amount of more than $\$ 36$ billion. Most of the lending was done through the primary-credit program. The seasonal-credit program was also a significant source of funding for banks during our sample period. In the span of those five years, the amount of primary credit shows a slow secular decline and the amount of seasonal credit has been gradually trending up but with large seasonal swings.

A significant proportion of the transactions reported in the data are likely to be "test" loans. These test loans tend to be for very small amounts and do not have a significant impact on the total amounts lent when aggregated across all loans. Still, for understanding the typical size of loans and other relevant aspects of the data, it is helpful to minimize the influence of test loans in the results. We choose a threshold of $\$ 10,000$ and exclude the loans at or below that threshold when we want to focus on the characteristics of nontest loans. In the case of secondary credit, this procedure leaves us with a very small number of nontest loans, which reduces our ability to draw robust inferences.

In contrast, for the case of the primary-credit program, the sample of nontest loans is large. The size of primary-credit loans is relatively widespread with some very large loans present in the sample. Most loans are overnight, but there are loans with up to a fourteen-day maturity term. A lot of banks accessed the primary-credit program during our sample period, and many of those banks used the program on sev-

eral occasions. Primary-credit loans are more common at the end of the month, the quarter, and the year, but in general there is credit extended at all times. Most of the primary-credit loans constitute onetime events, in the sense that they do not get rolled over. Those loans that do get rolled over tend to be somewhat larger on average and do not always get rolled over into equal or smaller amounts (sometimes they are rolled over into larger amounts).

Very large secondary-credit loans are rare. Abstracting from test loans, there are actually not many loans being granted through this program. Comparing secondary-credit loans with primary-credit loans, we see that the former tend to be smaller and of shorter term. This is consistent with the fact that those are loans offered at a higher interest rate, and the corresponding borrowers are subject to more supervisory scrutiny.

Consistent with its name, the volume of seasonal credit presents a strong annual seasonal pattern with lending generally picking up significantly in the second half of the year. Test loans are a lot less common in the seasonal-credit program, and loan size is more uniformly 
spread in the range of $\$ 1$ million to $\$ 15$ million. The maturity term is also widespread between one and thirty-plus days.

Collateral utilization is not concentrated around a certain level and does not tend to reflect a correlation with the size of the loans. Because collateral is measured adjusted for the appropriate haircuts and the utilization ratio is below unity for most of the loans, the level of credit risk involved in these transactions seems likely to be fairly low.

It is, of course, difficult to determine the appropriate amount of discount-window credit needed by US banks. Those needs are likely to also depend on the state of aggregate financial conditions. The period we study includes some episodes of heightened financial turmoil (such as at the peak of the European crisis in 2011) but not a fullblown financial crisis (in the US). Also, during our sample period, banks were holding significant amounts of excess reserves (and liquidity more generally), which likely reduced banks' needs for emergency funding. Still, the data we have analyzed here show that many banks do access the discount window regularly, suggesting that the routine provision of backup funding by the central bank is a valuable option for many participants in the US banking sector. 
APPENDIX

Table A1 Annual Average of Daily Loan Amount Outstanding $(\$ \mathrm{~mm})$

\begin{tabular}{|c|c|c|c|c|}
\hline Year & Primary credit & Secondary credit & Seasonal credit & Total \\
\hline 2003 & 34.038 & 1.264 & 62.698 & 98.000 \\
\hline 2004 & 42.115 & 0 & 110.923 & 153.038 \\
\hline 2005 & 52.673 & 4.212 & 142.462 & 199.346 \\
\hline 2006 & 58.962 & 0.154 & 165.538 & 224.654 \\
\hline 2007 & 479.750 & 3.192 & 104.846 & 587.788 \\
\hline 2008 & $31,817.943$ & 34.642 & 39.698 & $31,892.283$ \\
\hline 2009 & $40,221.212$ & 192.731 & 45.115 & $40,459.058$ \\
\hline 2010 & $4,429.154$ & 309.923 & 39.212 & $4,778.288$ \\
\hline 2011 & 25.942 & 0.173 & 35.942 & 62.058 \\
\hline 2012 & 22.981 & 0.019 & 49.442 & 72.442 \\
\hline 2013 & 13.173 & 0.019 & 65.462 & 78.654 \\
\hline 2014 & 12.830 & 0 & 104.755 & 117.585 \\
\hline 2015 & 17.250 & 0.019 & 107.404 & 124.673 \\
\hline 2016 & 17.808 & 0 & 83.615 & 101.423 \\
\hline 2017 & 13.212 & 0.019 & 81.846 & 95.077 \\
\hline
\end{tabular}


Figure A1 Distribution of Primary-Credit Loan Sizes. Log Amounts

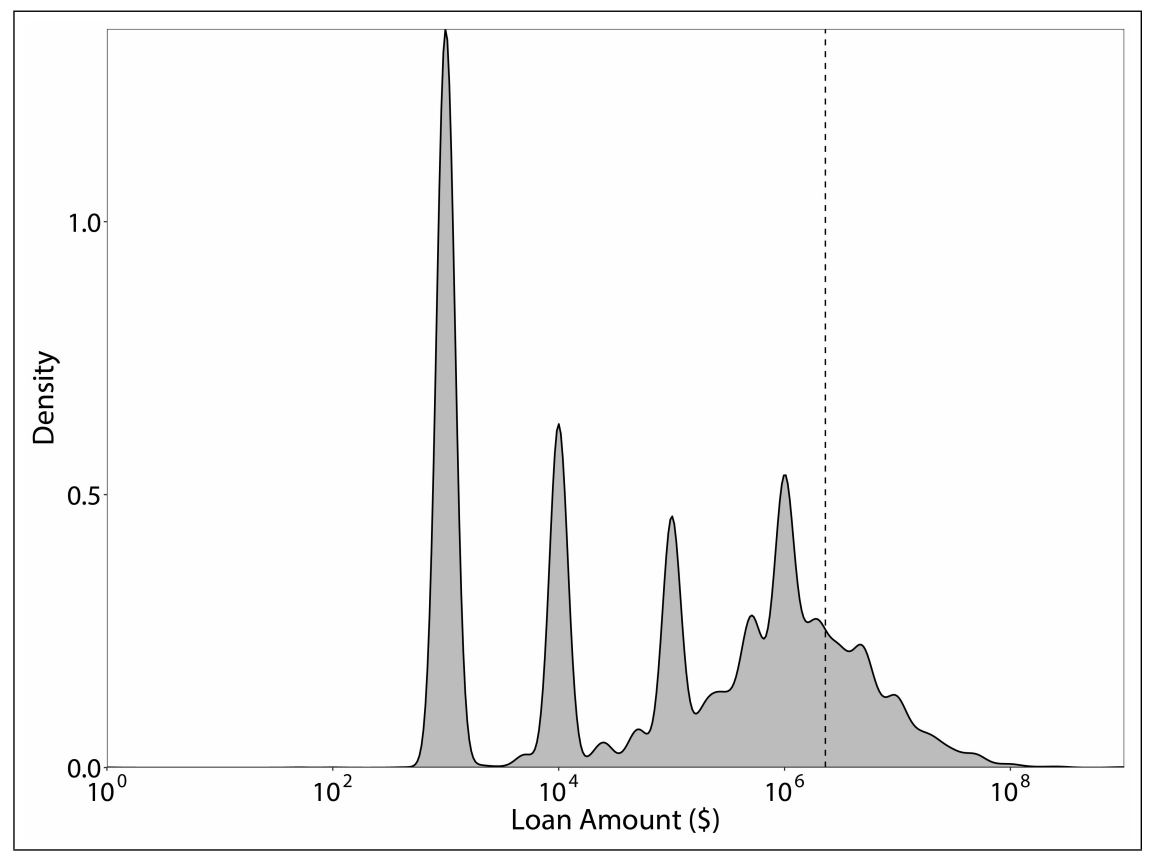

Note: We compute the distribution of primary-credit loan sizes after taking log of each corresponding amount. 


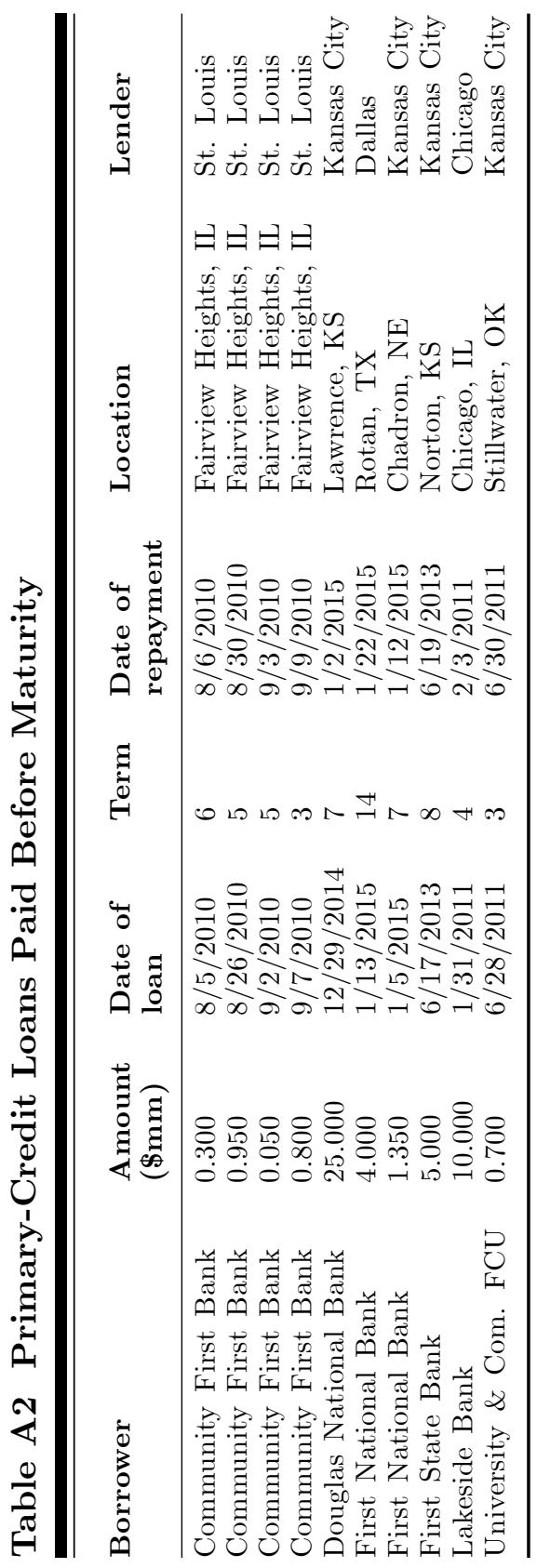


Ackon \& Ennis: The Fed's Discount Window

Table A3 Primary-Credit Loans from Texas Capital Bank

\begin{tabular}{llr}
\hline Date & Term & Loan amount $(\mathbf{\$ m m})$ \\
\hline $10 / 31 / 2011$ & 1 & 15.000 \\
$11 / 2 / 2011$ & 1 & 60.000 \\
$11 / 15 / 2011$ & 1 & 35.000 \\
$11 / 30 / 2011$ & 1 & 82.000 \\
$12 / 1 / 2011$ & 1 & 7.000 \\
$12 / 30 / 2011$ & 4 & 132.000 \\
$1 / 31 / 2012$ & 1 & 7.000 \\
$4 / 30 / 2012$ & 1 & 115.000 \\
$5 / 1 / 2012$ & 1 & 115.000 \\
$5 / 2 / 2012$ & 1 & 296.000 \\
$5 / 3 / 2012$ & 1 & 7.000 \\
$8 / 31 / 2012$ & 4 & 115.000 \\
$9 / 4 / 2012$ & 1 & 200.000 \\
$9 / 5 / 2012$ & 1 & 250.000 \\
$9 / 6 / 2012$ & 1 & 215.000 \\
$9 / 7 / 2012$ & 3 & 150.000 \\
$9 / 10 / 2012$ & 1 & 160.000 \\
$9 / 12 / 2012$ & 1 & 50.000 \\
$1 / 30 / 2013$ & 1 & 20.000 \\
\hline
\end{tabular}

Table A4 Loan Rollovers

\begin{tabular}{llr}
\hline $\begin{array}{l}\text { Number of } \\
\text { rollovers }(\mathbf{x})\end{array}$ & $\begin{array}{l}\text { Number of credit events } \\
\text { involving } \mathbf{x} \text { rollovers }\end{array}$ & $\begin{array}{c}\text { Average size } \\
\text { of loans }\end{array}$ \\
\hline 0 & 9000 & 1.649 \\
1 & 350 & 3.277 \\
2 & 146 & 3.631 \\
3 & 69 & 6.377 \\
4 & 37 & 2.594 \\
5 & 27 & 10.366 \\
6 & 16 & 6.427 \\
7 & 18 & 5.209 \\
8 & 7 & 3.101 \\
9 & 6 & 8.751 \\
10 & 7 & 4.405 \\
11 & 1 & 9.575 \\
12 & 5 & 3.58 \\
13 & 4 & 7.075 \\
14 & 2 & 0.85 \\
15 & 2 & 3.097 \\
16 & 1 & 13.929 \\
\hline
\end{tabular}


Figure A2 Distribution of Primary Loan Sizes. Evolution over Time

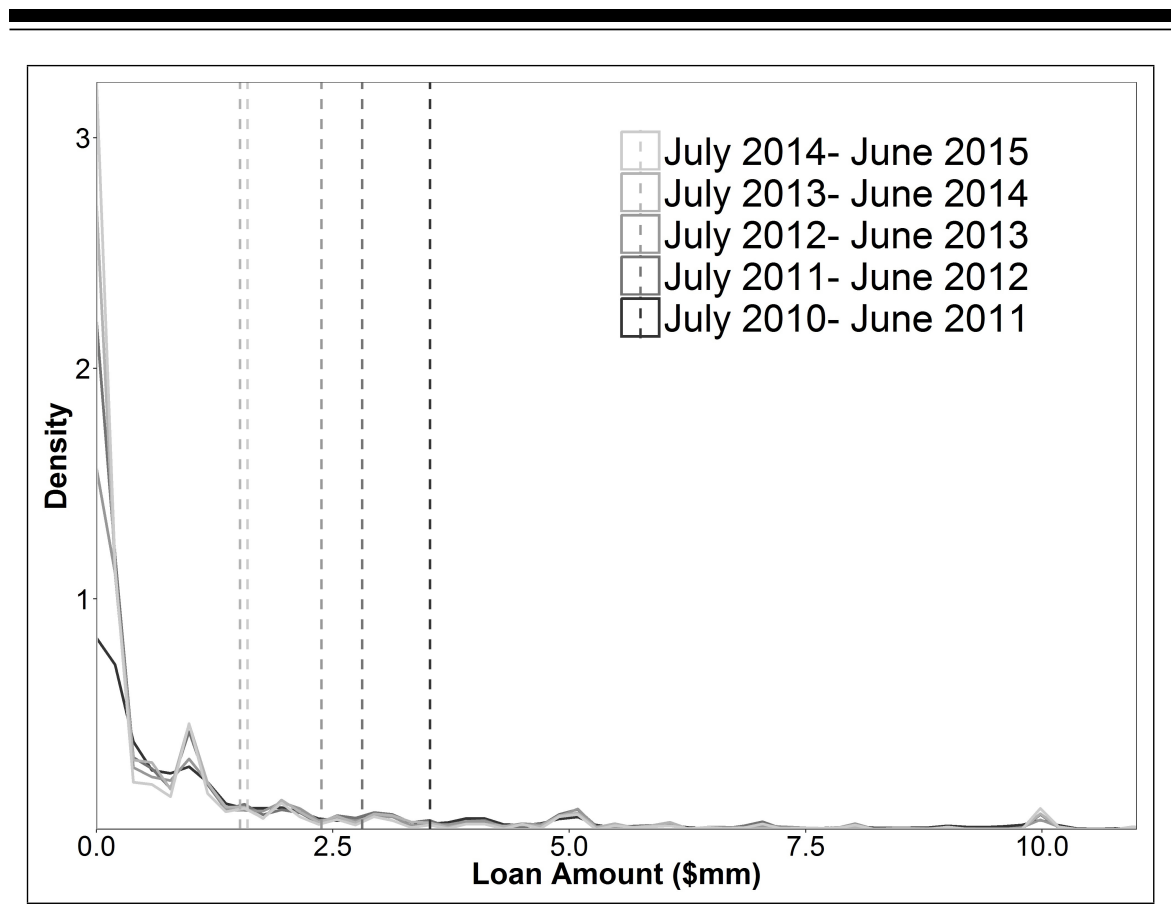

Note: We compute the distribution of primary-credit loan sizes for each twelvemonth period starting in July 2010. The distribution is calculated after excluding from the data all loans greater than $\$ 100$ million (fifteen loans in total for all five years). This helps to make the estimated distributions smoother. We then plot only the portion of the distribution that corresponds to loans of $\$ 10$ million or less. 


\section{REFERENCES}

Anbil, Sriya. Forthcoming. "Managing Stigma During a Financial Crisis." Journal of Financial Economics.

Armantier, Olivier, Eric Ghysels, Asani Sarkar, and Jeffrey Shrader. 2015. "Discount Window Stigma During the 2007-2008 Financial Crisis." Journal of Financial Economics 118 (November): 317-35.

Benmelech, Efraim. 2012. "An Empirical Analysis of the Fed's Term Auction Facility." Cato Papers on Public Policy 2: 57-91.

Berger, Allen N., Lamont K. Black, Christa HS Bouwman, and Jennifer Dlugosz. 2017. "Bank Loan Supply Responses to Federal Reserve Emergency Liquidity Facilities." Journal of Financial Intermediation 32 (October): 1-15.

Courtois, Renee, and Huberto M. Ennis. 2010. "Is There Stigma Associated with Discount Window Borrowing?" Federal Reserve Bank of Richmond Economic Brief 10-05 (May).

Drechsler, Itamar, Thomas Drechsel, David Marques-Ibanez, and Philipp Schnabl. 2016. "Who Borrows from the Lender of Last Resort?" Journal of Finance 71 (October): 1933-74.

Ennis, Huberto M. 2016. "Models of Discount Window Lending: A Review." Federal Reserve Bank of Richmond Economic Quarterly 102 (First Quarter): 1-50.

Ennis, Huberto M., and Alexander L. Wolman. 2015. "Large Excess Reserves in the United States: A View from the Cross-Section of Banks." International Journal of Central Banking 11 (January): 251-89.

Furfine, Craig. 2003. "Standing Facilities and Interbank Borrowing: Evidence from the Federal Reserve's New Discount Window." International Finance 6 (November): 329-47.

Kleymenova, Anya. 2016. "Consequences of Mandated Bank Liquidity Disclosures." Chicago Booth Research Paper 16-04 (November).

Vossmeyer, Angela. 2017. "Analysis of Stigma and Bank Behavior." Manuscript. 